\title{
A Novel Geotechnical/Geostatistical Approach for Exploration and Production of Natural Gas From Multiple Geologic Strata Phase I - Volume I: Overview
}

\section{Topical Report}

W.K. Overbey, Jr.

T.K. Reeves

S.P. Salamy

C.D. Locke

H.R. Johnson

R. Brunk

L. Hawkins

May 1991

Work Performed Under Contract No.: DE-AC21-89MC26026

For

U.S. Department of Energy

Office of Foscil Energy

Morgantown Energy Technology Center

Morgantown, West Virginia

By

The College of West Virginia

Beckley, West Virginia

and

BDM Engineering Services Company

Morgantown, West Virginia

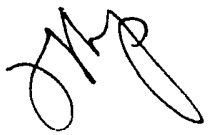




\section{DISCLAIMER}

This report was prepared as an accuunt of work sponsored by an agency of the United States Government. Neither the United States Government nor any agency thereof, nor any of their employees makes any warranty, express or implied, or assumes any legal liability or responsibility for the accuracy, completeness or usefulness of any information, apparatus, product, or process disclosed, or represents that its use would not infringe privately owned rights. Reference herein to any specific commercial product, process, or service by trade name, trademark, manufacturer, or otherwise, does not necessarily constitute or imply its endorsement, recommendation, or favoring by the United States Government or any agency thereof. The views and opinions of authors expressed herein do not necessarily state or reflect those of the United States Government or any agency thereof.

This report has been reproduced directly from the best available copy.

Available to DOE and DOE contractors from the Office of Scientific and Technical Information, P.O. Box 62, Oak Ridge, TN 37831; prices available from (615)576-8401, FTS 626-8401.

Available to the public from the Nationai Technical Information Service, U.S. Department of Commerce, 5285 Port Royal Rd., Springfield, VA 22161. 
A Novel Geotechnical/Geostatistical Approach for Exploration and Production of Natural Gas From Multiple Geologic Strata Phase I - Volume I: Overview

Topical Report

W.K. Overbey, Jr.

T.K. Reeves

S.P. Salamy

C.D. Locke

H.R. Johnson

R. Brunk

L. Hawkins

Work Performed Under Contract No.: DE-AC21-89MC26026

For

U.S. Department of Energy Office of Fossil Energy

Morgantown Energy Technology Center

P.O. Box 880

Morgantown, West Virginia 26507-0880

The College of West Virginia

P.O. Box AG

Beckley, West Virginia 25802-2830 and

BDM Engineering Services Company

1199 Van Voorhis Road, Suite 4

Morgantown, West Virginia 26505

May 1991 
MULTI-STRATA EXPLORATION PRODUCTION STUDY

PHASE I - VOLUME I - OVERVIEW

TABLE OF CONTENTS

PAGE

$\begin{array}{lll}1.0 & \text { INTRODUCTION } & 1\end{array}$

2.0 SUMMARY 1

3.0 RATIONALE AND APPROACH 3

3.1 Resource Generation 7

3.2 Reservoir Development and Modification 7

$\begin{array}{lll}3.3 & \text { Structural Control of Reservoirs } & 7\end{array}$

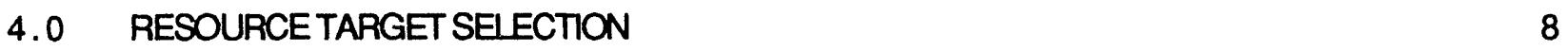

4.1 Regional Energy Resources $\quad 8$

4.2 Regional Geology 10

4.3 Target Formations 10

$\begin{array}{lll}4.4 & \text { Screening Criteria } & 20\end{array}$

$\begin{array}{ll}\text { 4.4.1 Selection of Target Coalbeds } & 20\end{array}$

4.4.2 Selection of Target Conventional Reservoirs 20

$\begin{array}{ll}\text { 4.4.3 Selection of Target Quadrangle } & 21\end{array}$

4.5 Eccles Quadrangle Analysis $\quad 21$

4.5.1 Eccles Gas Reservoirs $\quad 21$

4.5.2 Eccles Reservoir Characteristics 23

4.5.3 Eccles Structural Features 24

4.5.4 Eccles Component Optimization 24

5.0 GEOLOGY AND ENERGY RESOURCE DATACOUECTION 24

5.1 Database Development 24

5.2 Natural Gas Data Collection, Collation, and Analysis 26

5.3 Coalbed Methane Data Collection, Collation, and Analysis 26 
TABLE OF CONTENTS (continued)

6.0 DATA ANALYSIS AND DEVELOPMENT OF RESERVOIR MODELS 26

6.1 Sandstone Reservoir Model Development 28

6.2 Limestone Reservoir Model Development 28

6.3 Coalbed Reservoir Model Development 28

7.0 LOCATION OF HIGH PROBABILTY TARGET SITES 28

7.1 Development of Component Maps 29

7.2 Summary Component Optimization Maps 29

$\begin{array}{lll}7.3 & \text { Site Selection Process } & 29\end{array}$

$\begin{array}{ll}\text { BIBLOGRAPHY } & 35\end{array}$ 


\section{LIST OF ILLUSTRATIONS}

PAGE

Figure 2.0.1

Figure 2.0.2

Figure 2.0.3

Figure 2.0.4

Figure 4.0.1

Figure 4.3.1

Figure 4.3.2

Figure 4.3.3

Figure 4.3 .4

Figure 4.3.5

Figure 4.3.6

Figure 4.3.7

Figure 4.3 .8

Figure 4.5.1

Figure 5.3.1

Figure 7.1.1

Figure 7.1.3

Figure 7.1 .4

Figure 7.1.5
Figure 7.1 .2
Component Optimization Elements

Component Optimization Map

Projected Target Drilling Sites

Raleigh County, West Virginia

Generalized Geologic Column

Raleigh County, West Virginia, Area Mineable Beckley Coal Mined and Unmined Areas of Pocahontas \#3 Coal

Raleigh County, West Virginia, Area Natural Gas Fields

Raleigh County, West Virginia, Well Database

Structure on Top of the Berea

Eccles, West Virginia Quad Base Map

Mined Out Area of Eccles Quad West Virginia

Subsets of the Primary Elements

Subsets of the "Structure" Element

Big Lime Residual Structure Anomalies

Combined Natural Gas and Coalbed Methane Resource

Big Lime Present Day Reservoir
Optimized Well Locations

Raleigh County, West Virginia, Tax Districts

Raleigh County, West Virginia, Area Mineable Pocahantas Coal

2

4

5

6

9

11

12

13

14

15

16

18

19

22

27

30

31

32

33

34

\section{LST OF TABLES}

Table 2.1 
A Novei Geotechnical/Geostatistical Approach For

Exploration and Production of Natural Gas From

Multiple Geologic Strata

Phase I - Volume I - Overview

\section{$1.0 \quad$ INTRODUCTION}

This research program has been designed to develop and verify a unique geostatistical approach for finding natural gas resources. The research has been conducted by Beckley College, Inc. (Beckley) and BDM Engineering Services Company (BDMESC) under contract to the U.S. Department of Energy (DOE), Morgantown Energy Technology Center.

Phase $I$ of the project consisted of compiling and analyzing relevant geological and gas production information in selected areas of Raleigh County, West Virginia, ultimately narrowed to the Eccies, West Virginia, 7 1/2 minute Quadrangle. The Phase I analysis identified key parameters ccntributing to the accumulation and production of natural gas in Raleigh County, developed analog mociels relating geological factors to gas production, and identified specific sites to test and verify the analysis methodologies by drilling. Based on the Phase I analysis, five sites have been identified with high potential for economic gas production.

Phase II will consist of drilling, completing, and producing one or more wells at the sites identified in the Phase I analyses. The initial well is scheduled to be drilled in April 1991.

This report summarizes the results of the Phase I investigations. For clarity, the report has been prepared in two volumes. Volume I presents the Phase I overview; Volume II contains the detailed geological and production information collected and analyzed for this study.

\subsection{SUMMARY}

It is well known that a number of geologic factors interact to control the conditions of sediment deposition. Through geologic time, other factors affect the deposits, sometimes producing hydrocarbons and forming potential trapping mechanisms. Three major elements (the generation of resource, the formation of a reservoir, and the presence of favorable structural features) have been identified as the most significant factors associated with a high potential for hydrocarbon production. These elements are represented graphically in Figure 2.0.1. Each corner of this figure represents an optimum condition for that element, e.g., a high probability of the formation of reservoir conditions, a total gas resource greater than 8 million cubic feet/acre (MMct/acre), or favorable structural features. The key to identifying areas with a high potential for economic gas production lies in being able to locate regions where all the elements have combined at their best potential. This optimum or near-optimum condition is depicted at the center of Figure 2.0.1. The objective of the program was to locate areas where satisfactory conditions occured and to verify the analysis by drilling and completing one or more wells.

This Department of Energy project was initiated to develop a method to statistically analyze the geology of an area to identify, quickly and inexpensively, optimum conditions for hydrocarbon accumulation. The project was designed to: 


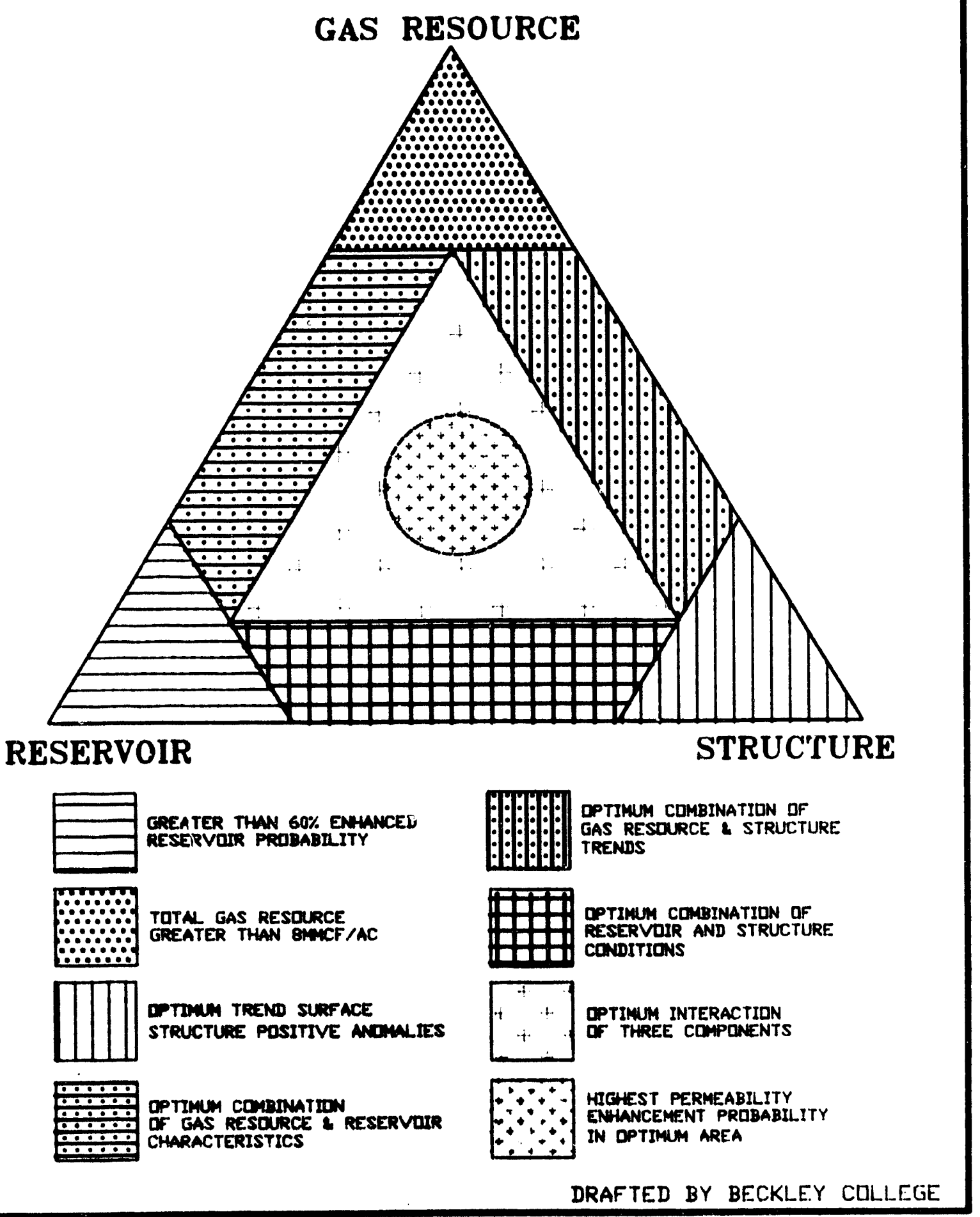

Figure 2.0.1

Component Optimization Elements 
develop a geostatistical exploration technique for locating wells which would include coal, as well as conventional sandstones, siltstones, limestones and shales as potential gas reservoirs;

locate and lease specific sites for drilling, well completion, and production;

verify the validity of the approach by drilling one or more test wells.

The project applied and tested the techniques in Raleigh County, but the methodology can be easily adapted to other areas where coal reserves co-occur stratigraphically with conventional natural gas reservoirs.

The approach described in this document was utilized in the Eccles Quadrangle, in Raleigh County, West Virginia. The results, displayed in Figure 2.0.2, show an area near the center of this quadrangle with the combination of gas resource, reservoir conditions, and structure needed for an optimum potential for commercial gas production. Lease ownership and existing well information were reviewed to locate drill sites in or near the optimum area. Five currently available well sites were selected as candidate locations to test the validity of the approach by drilling (FIgure 2.0.3). These sites, when overlayed on the Component Optimization Map (FIgure 2.0.4), show each site within or near the optimized area.

Economic analyses of each proposed wellsite was undertaken, with the results presented in Table 2.1. Proposed sites 1,2, and 3 clearly have the greatest economic potential, better than proposed sites 4 and 5. Accordingly, arrangements were made to obtain rights to drill up to three wells to test the analysis procedure developed under this project. The field work and resulting production will be documented in the Phase II report of this study

TABLE 2.1 - CASH FLOW ANALYSIS

FIVE PROPOSED DRILLING LOCATIONS

\begin{tabular}{|c|c|c|c|c|}
\hline \multirow{2}{*}{$\begin{array}{l}\text { PROPOSED } \\
\text { SITE NUMBER }\end{array}$} & \multicolumn{2}{|c|}{ SUCCESS RATIO $=100 \%$} & \multicolumn{2}{|c|}{ SUCCESS RATIO $=77 \%$} \\
\hline & $\begin{array}{c}\text { PAY-OUT } \\
\text { PERIOD, YRS }\end{array}$ & $\begin{array}{l}\text { INTERNAL } \\
\text { RETURN, \% }\end{array}$ & $\begin{array}{c}\text { PAY-OUT } \\
\text { PERIOD, YRS }\end{array}$ & $\begin{array}{l}\text { INTERNAL } \\
\text { RETURN, \% }\end{array}$ \\
\hline 1 & 1.5 & 44 & 2.1 & 34 \\
\hline 2 & 1.7 & 40 & 2.2 & 31 \\
\hline 3 & 2.1 & 26 & 3.3 & 19 \\
\hline 4 & 3 & 17 & 4.7 & 12 \\
\hline 5 & 2.3 & 25 & 3.5 & 18 \\
\hline
\end{tabular}

\subsection{BATIONALE AND APPROACH}

The definition of a successful hydrocarbon exploration and development program is the prediction of where resource can be found. Of the various factors that have some bearing on the 


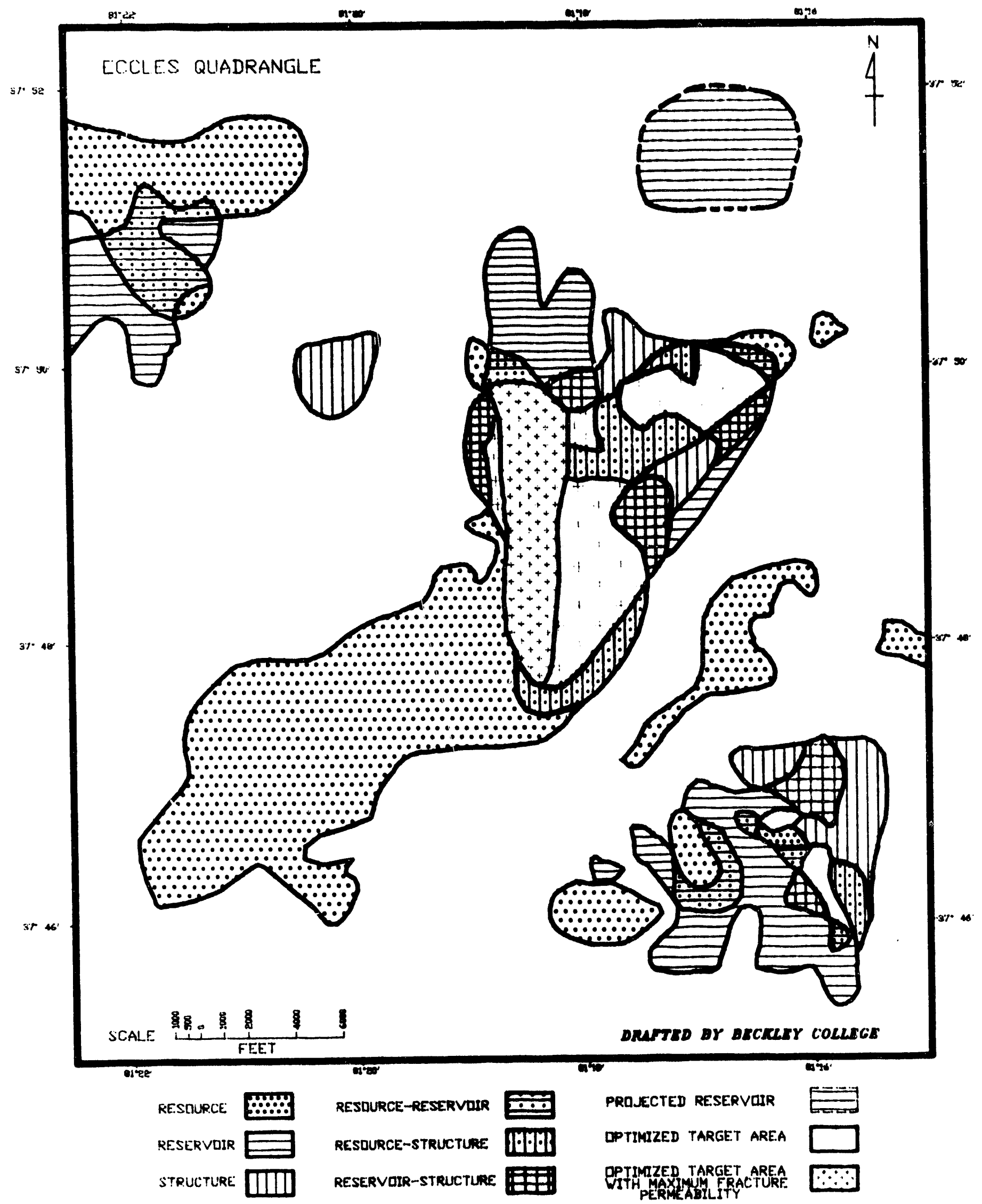

Figure 2.0.2 Component Optimization Map 


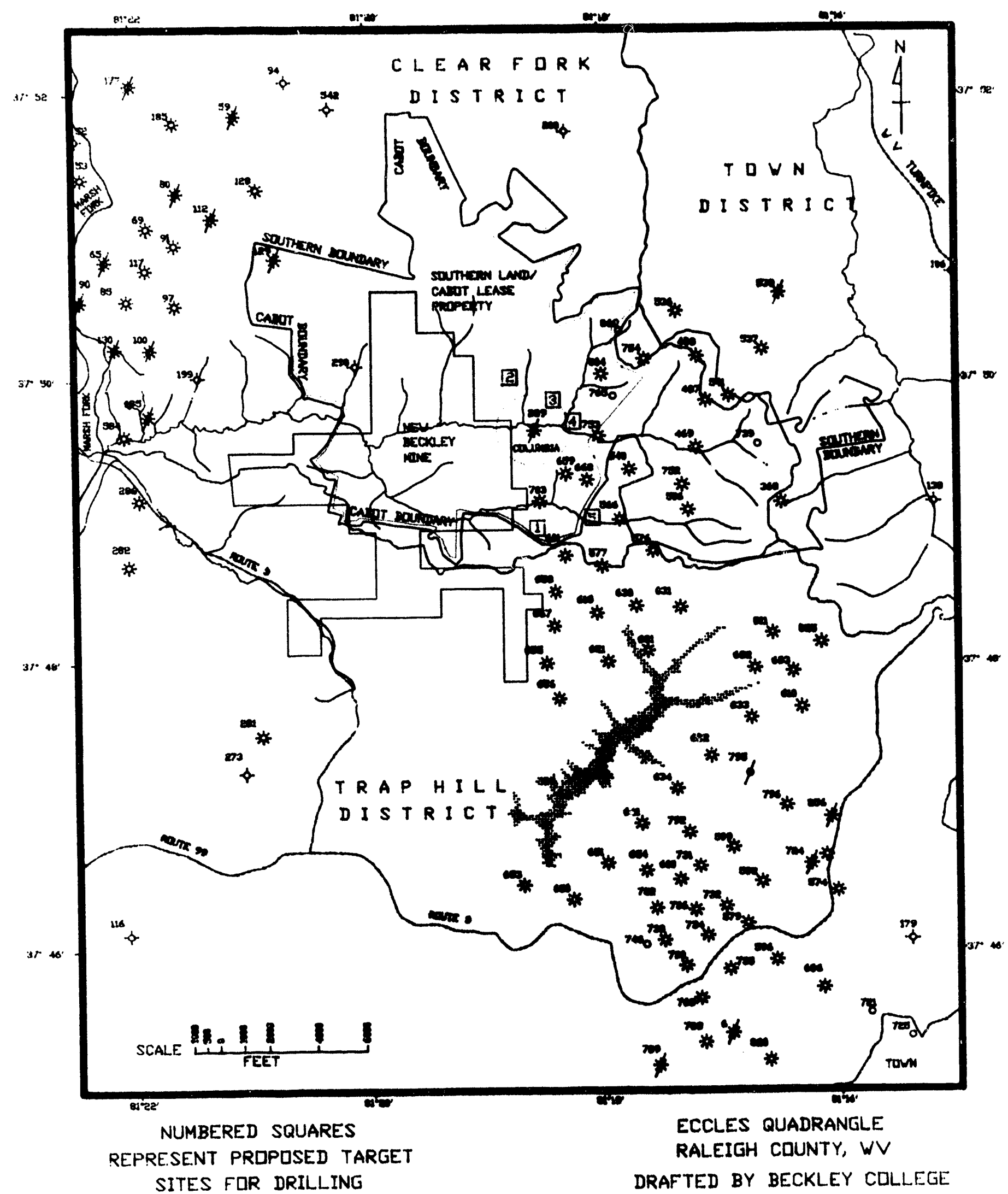

Figure 2.0.3

Projected Target Drilling Sites 


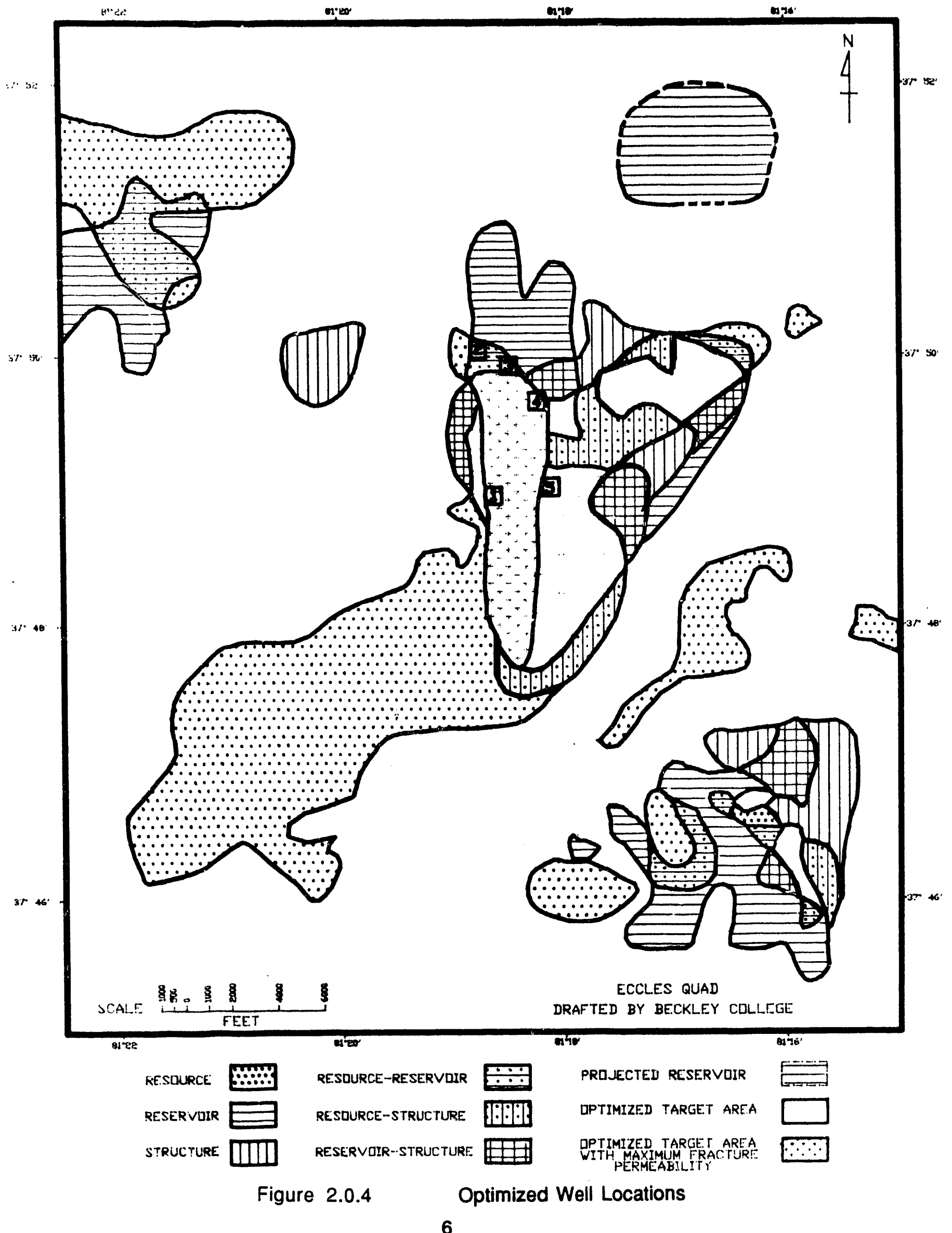


successful production of hydrocarbons from the earth, the dominant elements are the sediments which generate the gas and oil through the application of heat and pressire over time (the source beds), the formations which b-?come containers for the oil and gas (the reservoirs), and the mechanisms which direct, trap and hold the c,as in the reservoir space (iricluding the structural position). These factors of resource generation, rejervoir development and structure all interact to control an accumulation of gas and/or oil, and determine if it will be found in sufficient quantities to allow economic production when drilled. The following discussion outlines the basis for the work performed in Phase 1 of this project.

\subsection{Resource Gencration}

Most sedimentary hydrocarbon reservoir rocks are deposited along the margins of ocean basins, on river plains or deltas, or in shallow fresh water lakes and swamps. Such sediments usually contain organic matter which can be converted to hydrocarbons. If there are no sedimentary rocks with organic matter in a region, hydrocarbons are not likely to be found there. In the study area, sufficient organic matter was mixed in the Mississippian-age shaies, siltstones and limestones to generate large volumes of ras. This was also the case with the Pennsylvanian-age sediments, dominantly organic-rich river, delta, and coal swamp deposits, all of which generated much gas. The depositional environment of the coal measures was influenced by subtle structure, controling where the swamps were located and where the river and stream channels flowed and built deltas.

The locations of source beds were mapped and the geologic conditions that prevailed during deposition were interpreted as an aid to identifying potential reservoirs. The interaction of the primary sets (resource, reservoir, structure) and their subsets produce a universe of complex combinations which may influence the possibilities for commercial gas accumulations.

\subsection{Reservoir Development and Modification.}

Sedimentary rocks are generated by the deposition and compaction of grains or fragments of minerais and other rocks. There is usually some space between the particles within a sedimentary rock which is available to store water, gas, and/or oil. Sometimes the pore space is increased by solution by fluids moving slowly through the rocks or decreased by precipitation from similar fluids. The geochemistry of the sediments and fluids, temperature and pressure, the presence or absence of clays or mineral coatings surrounding the pore spaces, and the mix of water or hydrocarbons may alter these processes.

In the study area, excellent quality sandstone reservoir rocks were deposited in the Ravencliff interval, but they were later modified during the movement of fluids to greatly reduce reservoir pore space and permeability. Examination of logs, production tests and well records allowed the development of a series of models of the types of reservoirs to be found in the area. Additional analysis predicted where similar depositional environments and reservoirs might be found and helped determine the probability of encountering commercia! gas production at any given location on the map.

\subsection{Structural Control of Reservoirs}

Because hydrocarbons are lighter than water they accumulate in reservoir rocks above conate waters. Many of the world's greatest accumulations of oil and gas have been found in areas that are structurally high by several $10^{\prime}$ 's to $100^{\prime}$ 's of feet. Structurally high areas can form by tectonic folding of beds into anticlines or by faulting. Faulting, either normal or thrust, produces associated fractures which can provide additional, "secondary" porosity reservcir space for hydrocarbon accumulation.

There are no major structural features, either shallow or deep, within Raleigh County. This area is bounded on the west, in Boone and Logan Counties by the Rome Trough (a Late Pre-Cambrian rift 
system) and on the east, in Monroe, Greenbrier and Pocahontas Counties, by significant Basement faulting under the Appalachian foreland folds and thrust faults. Two minor anticlines (the Pineville and Mullins structures) enter the county from the southwest out of neighboring Wyoming County. Both folds die out in Raleigh County. No anticlines or synclines cross the county. This lack of intense tectonics and of strong structural features has most likely helped trap large volumes of methane in the coal seams of Raleigh County. In more intensely deformed areas, resource may escape and vent through fractures that are open to the surface.

Structural highs with hydrocarbon accumulations can also form by passive drape of sediments over buried hills on an eroded terrain. In West Virginia, the McCrady formation is noted for its buried hills. Greenbrier Limestone beds deposited on top of these hills may contain gas. Subi.e Basement structures were found to have influenced the accumulation of hydrocarbons in the Greenbrier Limestone in the study area.

\subsection{RESOURCE TARGET SELECTION}

Raleigh County is located geographically in south-central West Virginia (see Figure 4.0.1). The County is rich in mineral resources, including coal, coal-bed methane, and conventional natural gas. This section will provide an overview of:

the energy resources of Raleigh County;

the Raleigh County regional geology;

the target formations considered in this analysis;

the screening criteria used to sort the data into manageable components;

and the methodology used to arrive at the locations selected for drilling.

\subsection{Regional Eneray Resources}

Coal is the primary energy resource found in Raleigh County. The history of early production can be traced back to the $1780^{\prime}$ s, when it was mined mostly for local use. As rails were laid throughout the area, the mining of coal increased in importance. Current production rates are typically 8 million tons per year from more than 90 mines. For every ton of coal that is mined, approximately 300 cubic feet of methane gas is also produced and mostly vented to the atmosphere.

Of the 3 billion tons of mappable and minable coal originally found in Raleigh County, 1 billion tons have already been mined. More than 300 billion cubic feet (Bcf) of methane have also been produced, with most of this being vented directly to the atmosphere and thus wasted as a potential energy source (Ref. 1).

Oil and natural gas wells have been drilled in West Virginia since the 1800 's. Natural gas has been produced in Raleigh County from several Pennsylvanian-, Mississippian-, and Devonian-aged formations. However, many of the shallow formations have proven to be economically marginal which has inhibited intensive development by the major companies or independent operators in the area.

The concept of co-production of methane from coal along with natural gas from more conventional sources is an idea that can benefit both resources. To prove the validity of this concept in field 


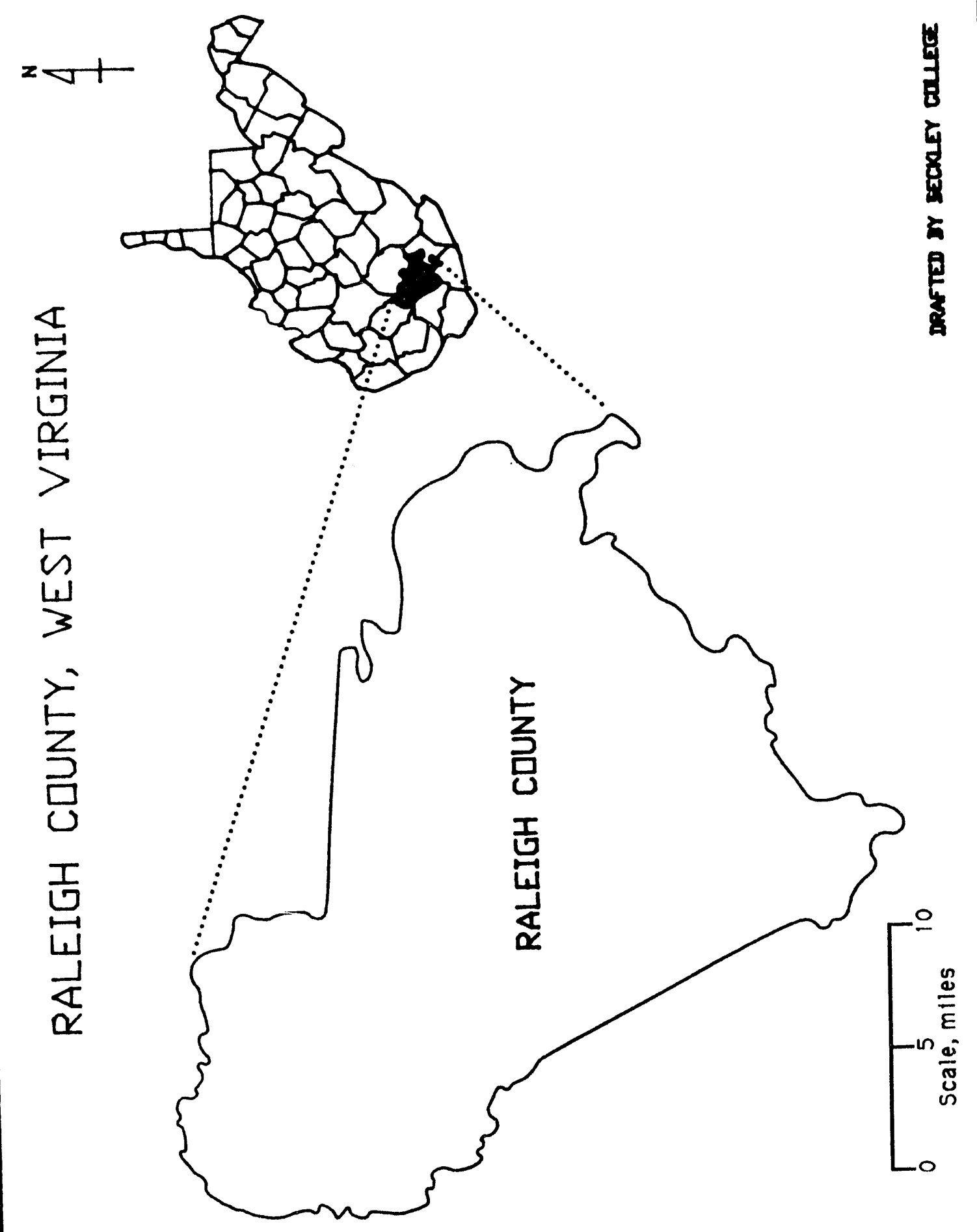

Figure 4.0.1

Raleigh County, West Virginia 
applications, it has been necessary to locate areas where a single well could penetrate coal as well as conventional reservoirs, select and lease suitable well site locations, drill one or more wells, dually complete the wells, and establish commercial gas production.

\subsection{Regional Geology}

Raleigh County underwent relatively little tectonic deformation during the Paleozoic Orogenies. The Lower Paleozoic sediments in the area are still essentially flat-laying, thickening gradually to the east and north. They were tilted to the northwest during the Alleghenian Orogeny. Modern regional dip is toward the northwest, with a series of low discontinuous folds following the regional Appalachian southwest-northeast structural grain.

Deep incision by rivers and streams has produced high relief across the study area, with hiltops generally four hundred to five hundred feet above stream valleys. Resistant Pennsylvanian-age sandstones form numerous cliffs along the steep hillsides.

The Basement underlying the study area is believed to be cut by a series of North-South-oriented faults that have shifted occasionally through time, producing minor tectonic fracturing and secondary porosity in the overlying sedimentary section. With a relatively thin sedimentary section and limited porosity, natural gas production in Raleigh County has been small compared to many of the West Virginia counties to the west and north where the sedimentary section is much thicker, with more intense structural disturbance.

\subsection{Iarget Formations}

A generalized geologic column for Raleigh County, WV (FIgure 4.3.1), reveals a number of coal seams with gas potential, as well as a number of conventional reservoir formations with hydrocarbon production potential. For this study, the Pennsylvanian-age deposits were considered in detail, as were the Mississippian-aged deposits, from the top down through the Big Lime. Formations deeper than the Big Lime were judged to be too deep to be effectively co-produced with coal seams, and were not, therefore, considered in this study.

The initial study area in Raleigh County included four Quadrangles - Beckley, Crab Orchard, Eccles, and Lester - shown in Figure 4.3.2. Within this area, the primary coals considered in the analysis included the:

Beckley Seam (Figure 4.3.3), the major mined coal in most of Raleigh County;

Pocahontas \#3 coal (Figure 4.3.4), which is being mined on the Beckley, Crab Orchard and Lester Quadrangles (FIgure 4.3.5) but not on the Eccles Quadrangle, where it is too deep; and

Sewell, \#2 Gas and Matewan or Upper Eagle Coal Seams, which are more limited in extent and thickness than the Beckley or Pocahontas coals.

Conventional natural gas has been found on each study area quadrangle (Flgure 4.3.6). The formations of potential interest to this project include the:

Salt Sands, which have had widely scattered production at depths in the hundreds to $1000+$ foot range; 


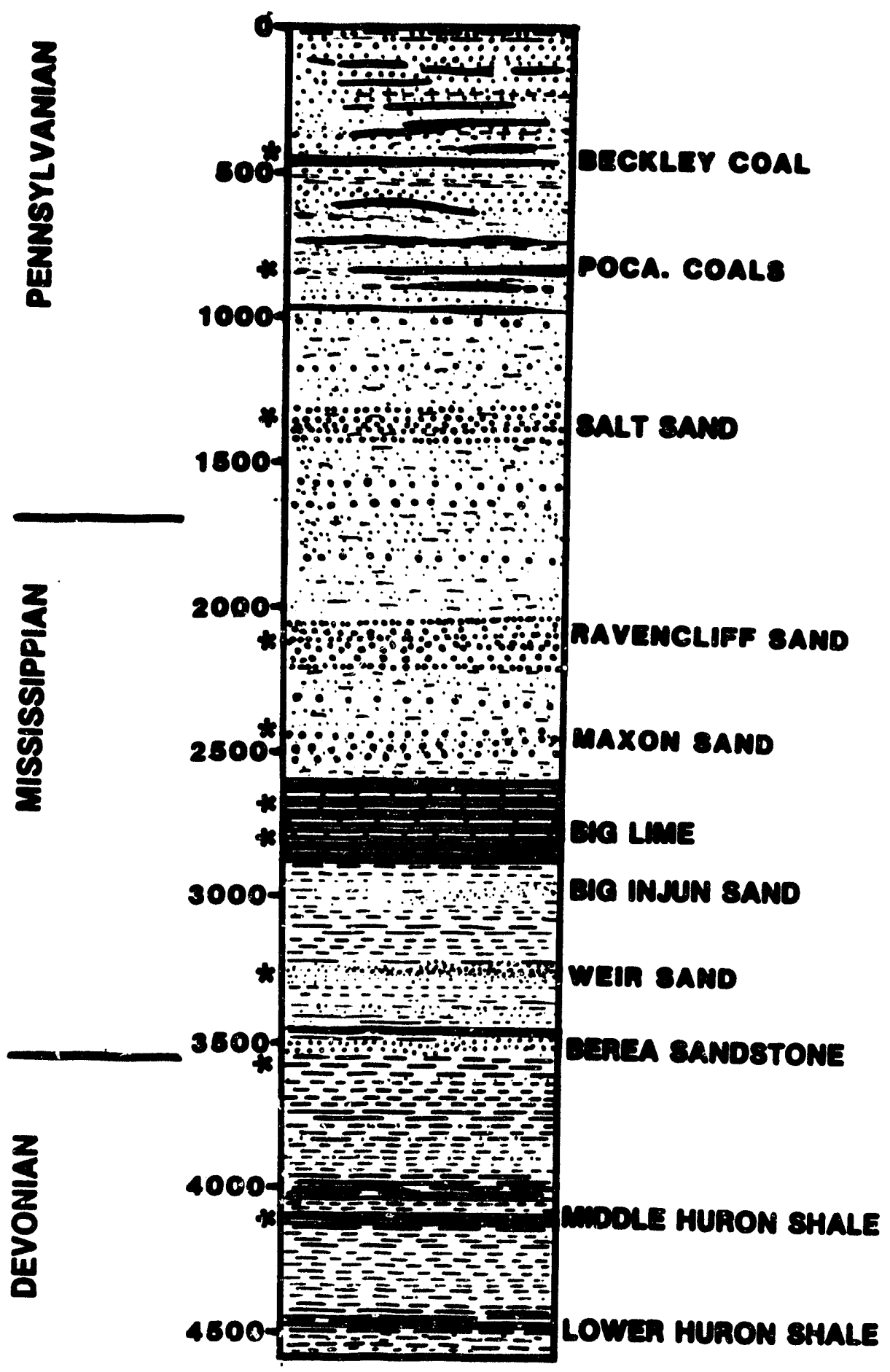

* Oll or cas paoouction

Figure 4.3.1 Generalized Geologic Column 


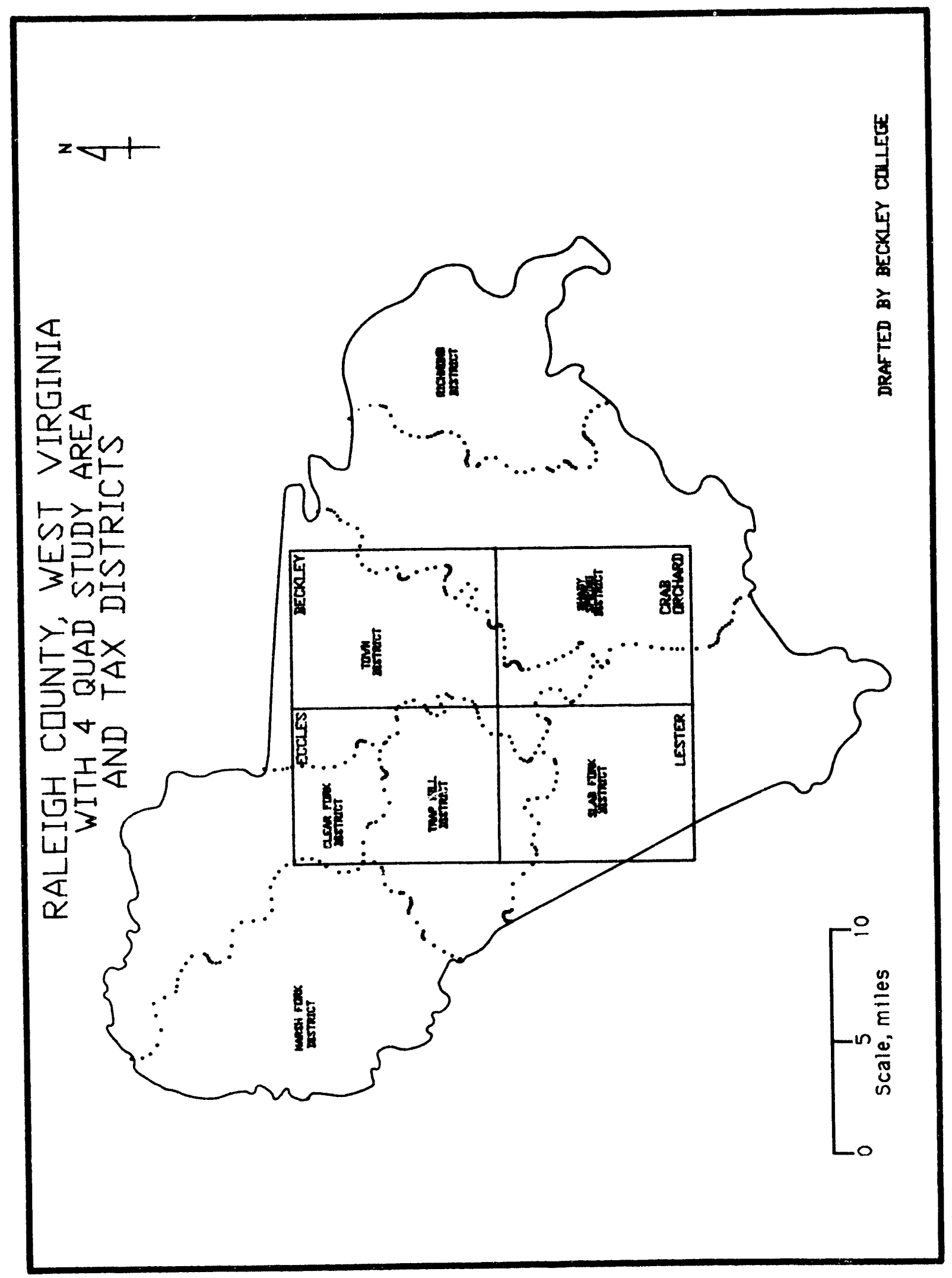

Figure 4.3.2

Raleigh County, West Virginia, Tax Districts 


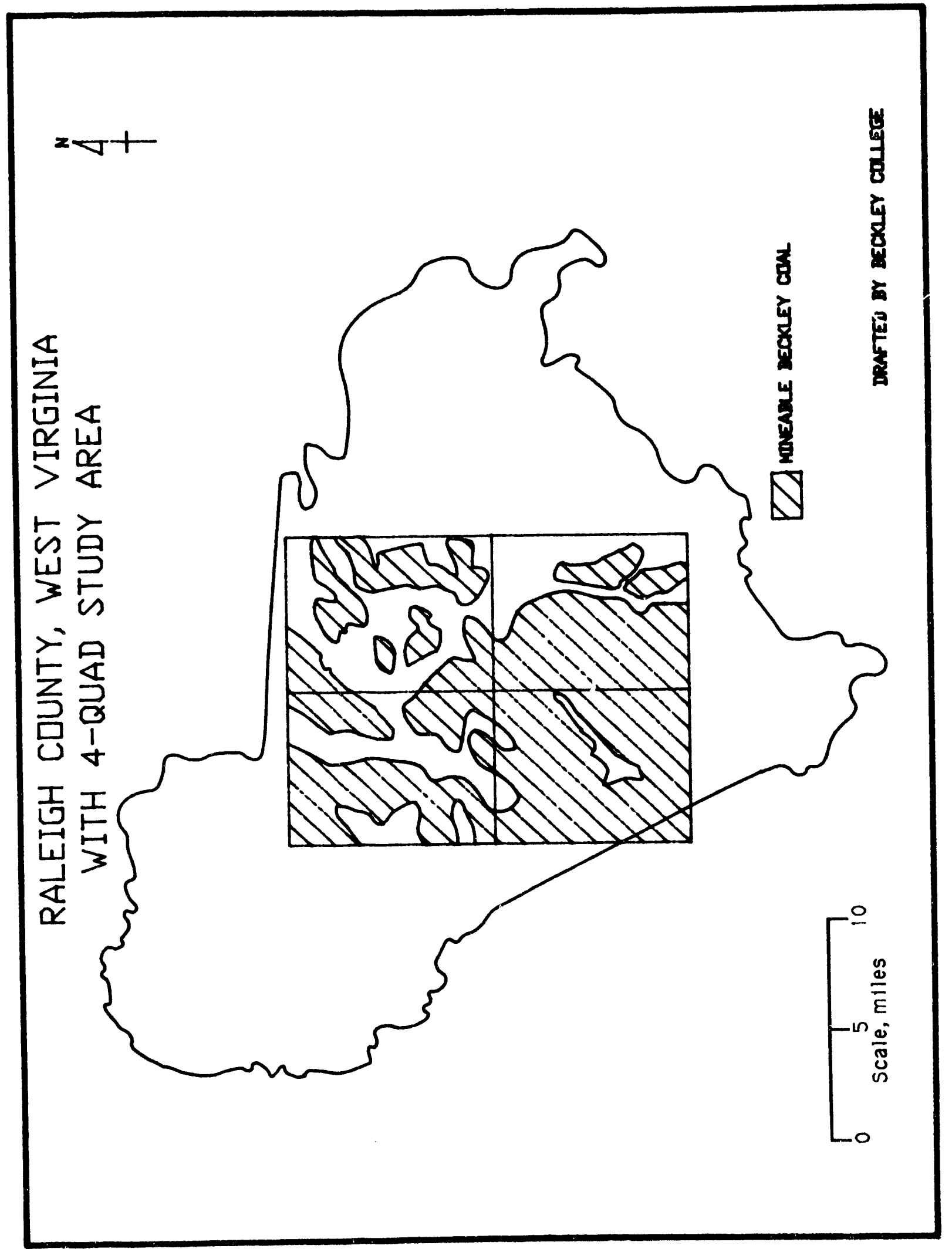

Figure 4.3 .3

Raleigh County, West Virginia, Area Mineable Beckley Coal 


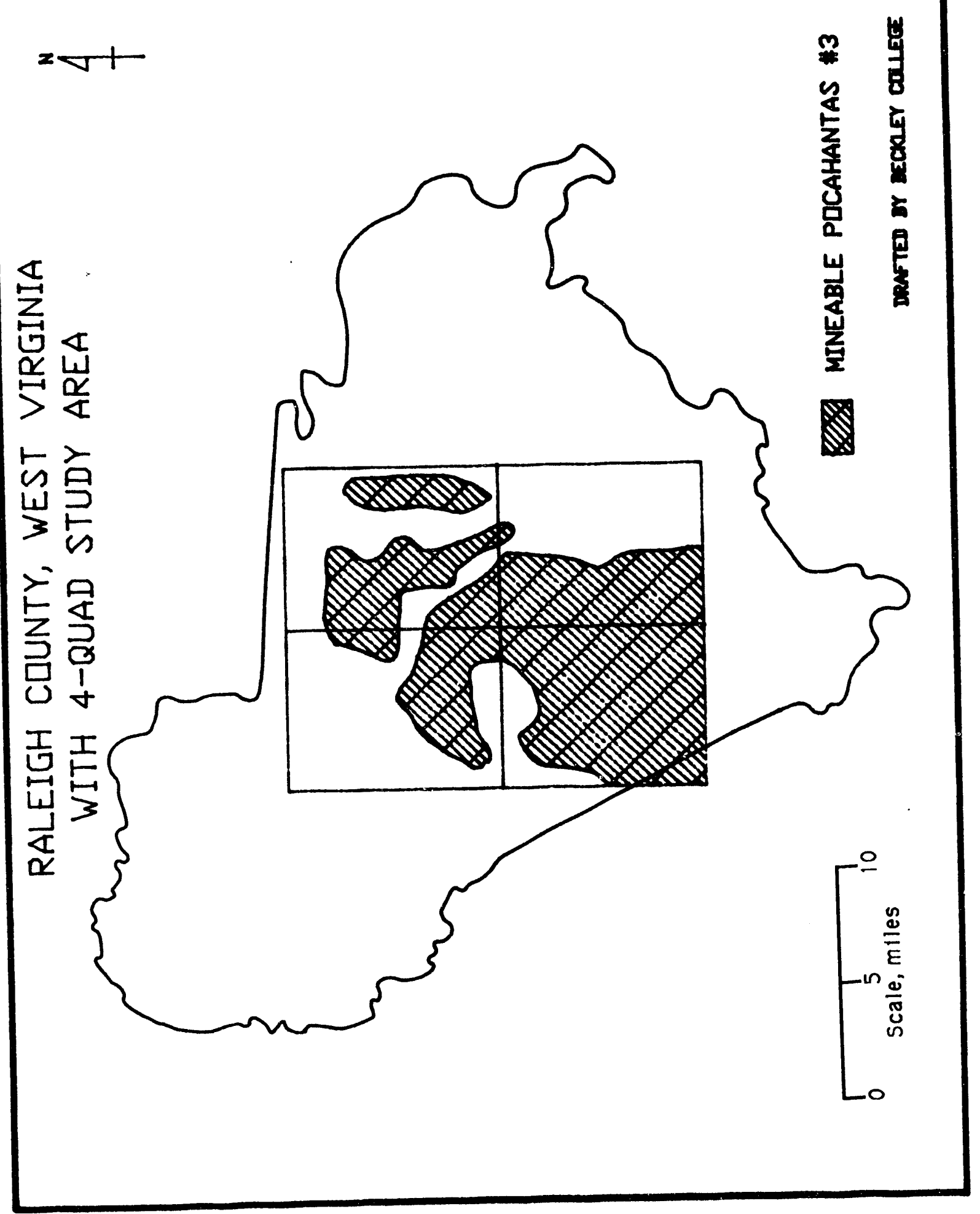

Figure 4.3 .4

Raleigh County, West Virginia, Area Mineable Pocahantas Coal 


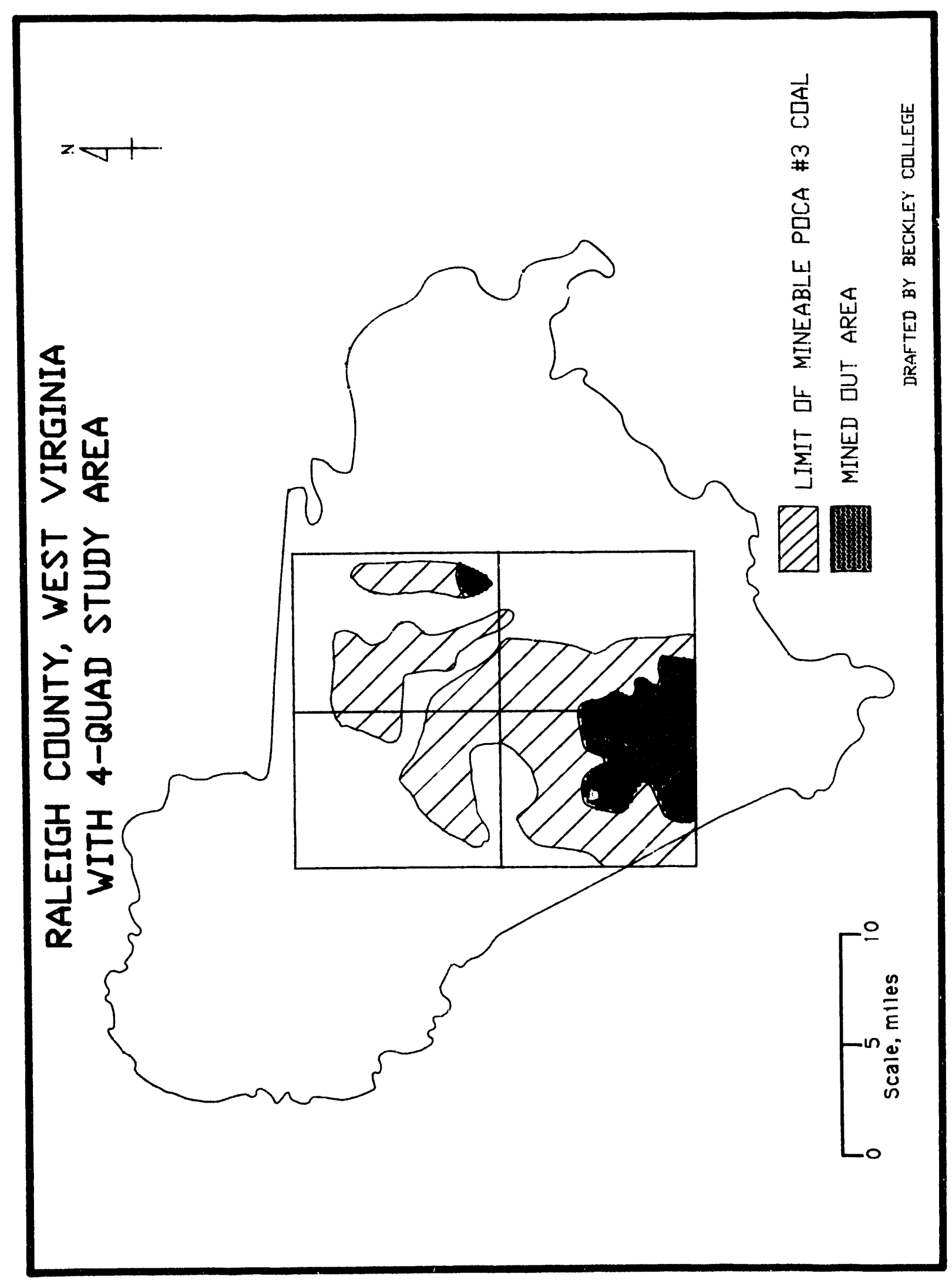

Figure 4.3.5 Mined and Unmined Areas of Pocahontas \#3 Coal 


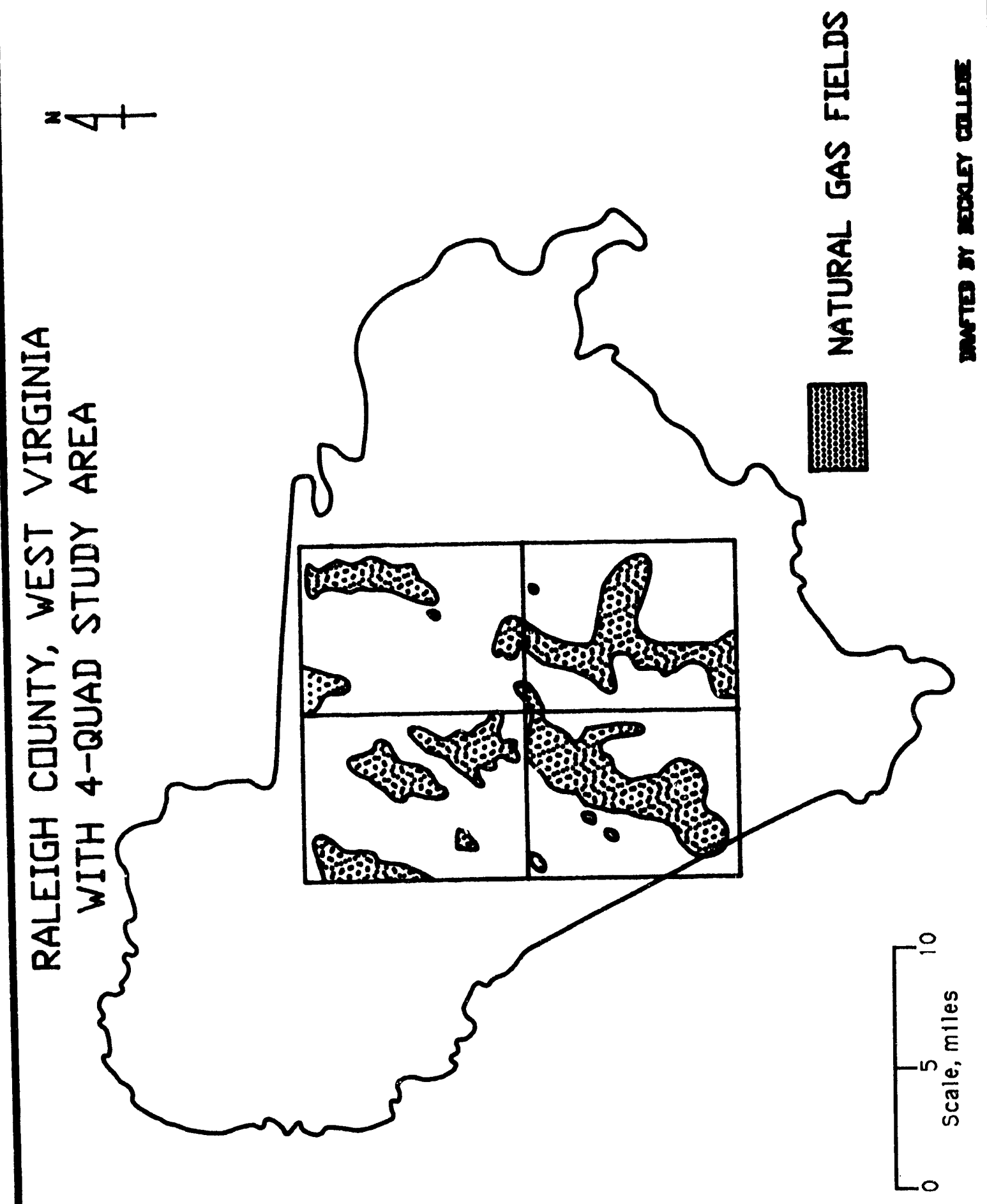

Figure 4.3.6

Raleigh County, West Virginia, Area Natural Gas Fields 
Ravencliff and Maxton family of sands, at depths generally from 1500 to $2500+$ feet;

Chesterian-age Greenbrier limestone, herein referred to by the drillers' term "Big Lime", the major reservoir in the Eccles area, roughly between 2500 and 3200 feet in depth; and

Weir and Berea Sands, which have had widely scattered shows and limited production in the region, but which do not seem to have any significant reserves in this immediate area, generally below 3000 feet in depth.

Below these potential targets, there are possible deeper reserves in the Devonian Shale section. The Shale potential is largely undefined since it has been tested recently by only a single modern shale test. At still greater depths are reservoirs in the Oriskany and Tuscarora Saridstones which were too deep for consideration in this project. Geologic structure and isopach maps were prepared for the key formations on the Beckley, Eccles, Lester and Crab Orchard Quadrangles. In addition, numerous largeinterval isopach maps were prepared to identify long term depositional and structural trends. The following key formations were mapped:

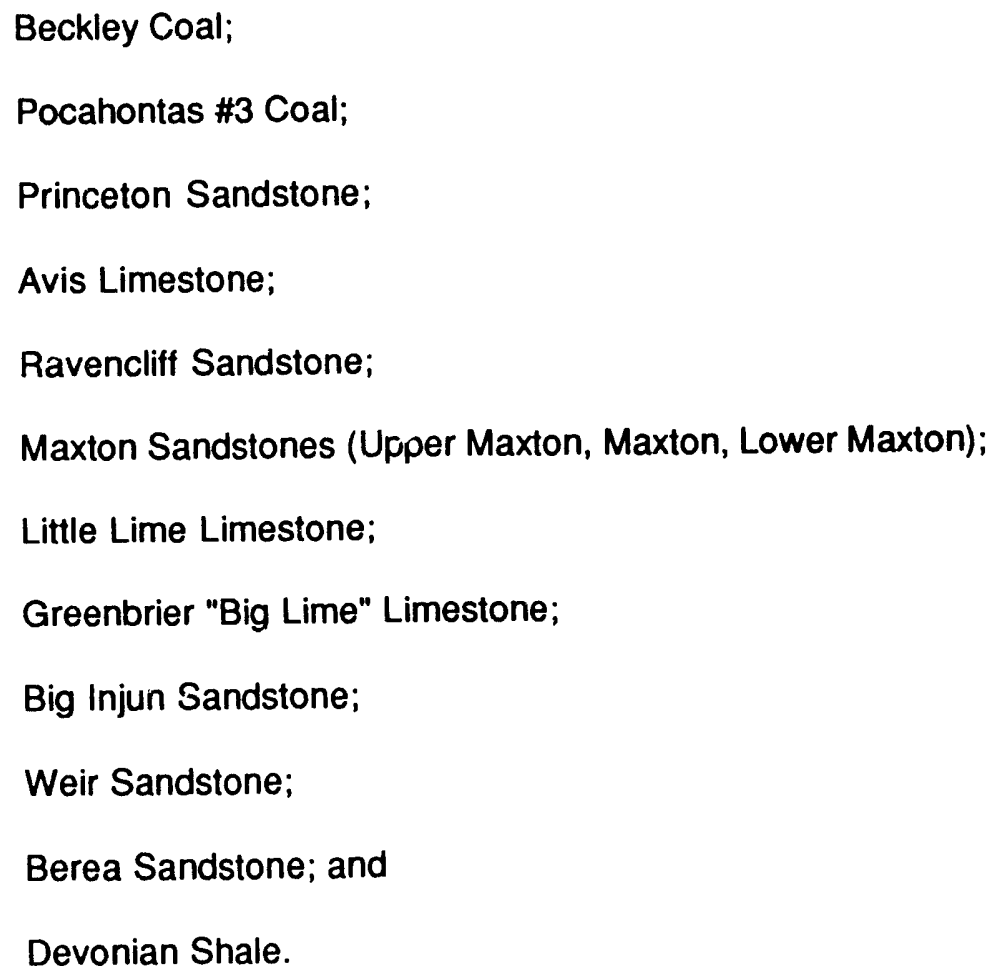

The wells included in the four quadrangle data base developed for this study are shown in Figure 4.3.7. Figure 4.3.8 is an example of the structure as mapped on top of the Berea in the four quadrangle area.

For the methane resource determination, the coal maps were reviewed, the Beckley and Pocahontas \#3 seams were isopached, their thicknesses combined and the total gas resource-in-place determined. The analysis accounted for mined-out areas and for shallow depth of burial.

For the conventional reservoirs, a color-coded set of maps was prepared showing the four quadrangle study area, indicating which wells produced from which formation. Many of the wells were 


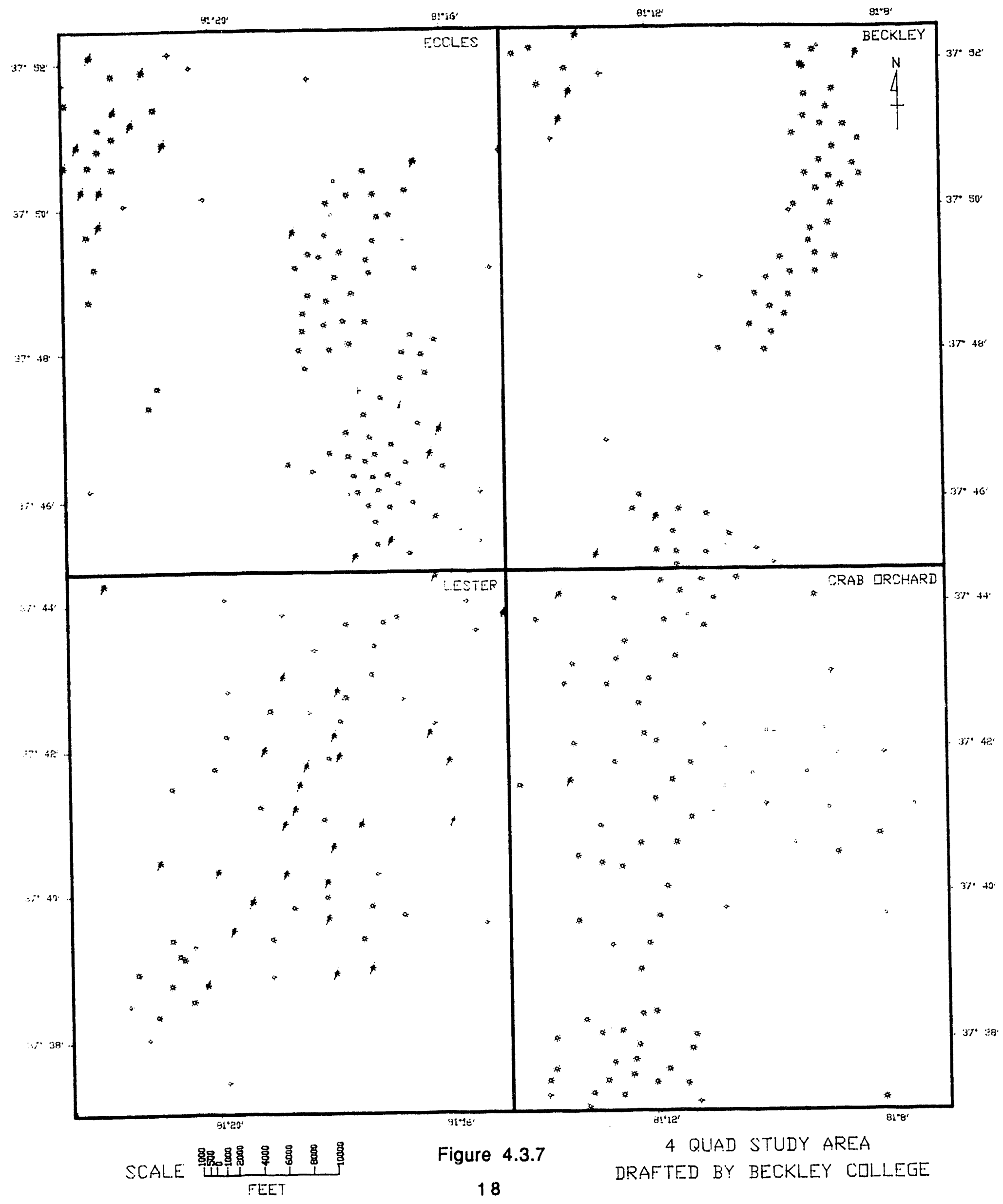




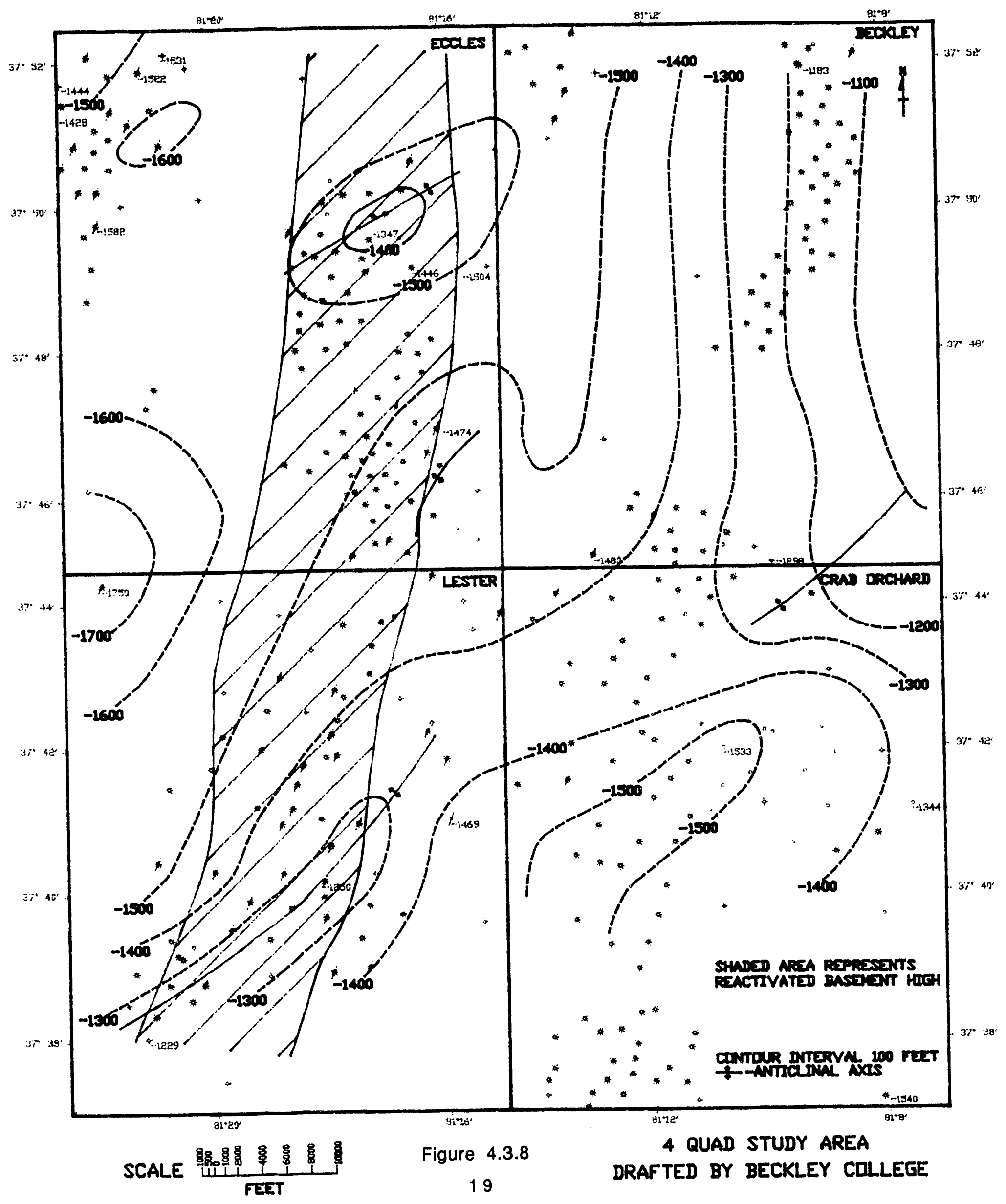


found to be producing from more than one formation, generally including the Big Lime and the Ravencliff. To determine the natural gas resource richness, the data were reviewed to determine remaining gas reserves.

\subsection{Screening Criteria}

A four quadrangle area database was developed in order to select a single quadrangle to be analyzed in detail within the time and budget allocated for this project. Criteria were developed to screen each coalbed and each conventional gas reservoir formation within each quadrangle.

\subsubsection{Selection Of Target Coalbeds}

There are more than seven significant coalbeds in the Raleigh County area, although many of these clearly could not make a major methane contribution to the project. To select coalbeds which could be economic methane producers, the seam needed to:

be greater than 24 inches in thickness;

be below drainage in most of the study area;

have an overburden greater than 800 feet; and

contain at least 100 standard cubic feet of gas per ton of coal in place.

After screening the coals using these factors, the \#2 Gas, Powellton, Eagle, Sewell, and Fire Creek Coals were eliminated from further consideration. The Beckley and Pocahontas \#3 coals were selected as target coalbeds for more detailed analysis and study. Additional Pocahontas seams near the \#3 might also come into play at any given location.

\subsubsection{Selection Of Target Conventional Reservoirs}

There are at least seven potential conventional natural gas reservoir formations in Raleigh County, West Virginia. To determine the producing horizons that should be included in the multi-strata study, the units were screened using the following criteria:

the unit needed to be mappable over fifty percent of the quadrangle study area;

the unit needed to be productive in at least twenty percent $(20 \%)$ of the producing wells drilled in the study area;

the depositional environment for the productive unit needed to be identifiable and must have been the subject of published studies or unpublished graduate theses or dissertations; and

data relative to reservoir properties needed to be available in public reports from the West Virginia Geological Survey (WVGES) or from geophysical well logs and well completion reports.

Producing formations which passed the screening criteria include the Ravencliff Sandstone and the "Big Lime" Limestone. The Salt Sands, Maxton Sands, Weir and Berea formations were considered but did not meet the screening criteria. 


\subsubsection{Selection of A Target Quadrangle For Detailed Study}

Comparative analyses were conducted to reduce the four quadrangle area to a single quadrangle which could be subjected to detailed study within the budget available.

The primary coal targets for the study were the Beckley and Pocahontas \#3 seams. The Lester Quadrangle originally had the largest area of minable coals, but was also the most extensively mined, cc.ssing much of the methane resource to be dissipated. The thicker coals have also been mined on the Beckley Quadrangle. Mining has been moderately extensive on the Crab Orchard Quadrangle. In addition, the key coals were 'c'o shallow for good methane production on the Beckley and Crab Orchard Quadrangles, where they oldtcrop.

In summary, the Eccles Quadrangle has deeper coals and more coal remaining in place than the other study area quadrangles. The study showed that the Eccles Quadrangle had both the greatest coalbed methane resource remaining and ample overburden thicknesses.

The conventional natural gas resources were also compared. The Lester Quadrangle was eliminated as a target area due to the extensive development, mostly by older wells lacking adequate data for this computerized analysis process, and to limited remaining drilling locations. The Beckley and Crab Orchard Quadrangles had scattered older exploratory wells, but no significant older production that could be identified from the study data base. The key deeper producing formations, including the important Big Lime, seemed to be dry on these maps. However, a recent drilling boom for gas has been stimulated on the Beckley and Crab Orchard maps by Wrightstone's report on the Ravencliff " $F$ " Channel (Refs. 5 and 6).

On the Eccles Quadrängle, a variety of formations are producing, including the Ravencliff, possibly the slightly deeper Maxton, the still deeper Big Lime, and the Weir Sandstone, which is beyond the depth limits considered in this project.

It was conclujed that the greatest potential for shallow conventional natural gas resource development lay in areas with both Pennsylvanian and Mississippian reserves. This eliminated the Beckley and Crab Orchard Quadrangles for conventional nalural gas potential, as well as for methane. For conventional natural gas, as with coalbed methane, the Eccles Quadrangle offered the best opportunities applying the study techniques.

Since the Eccles Quadrangle had the largest remaining coalbed methane resources and the best opportunities for shallow conventional gas resource development, it was selected for more detailed analyses.

\subsection{Eccles Quadrangle Analysis}

The Eccles Quadrangle (Figure 4.5.1) was chosen as the location for the detailed study. The project analysis focused on and related three major elements - gas resources, reservoir characteristics, and reservoir structurs - which yielded clues for identifying areas with a high potential for future drilling and development.

\subsubsection{Eccles Gas Resources}

Conventional natural gas and coalbed methane gas resources were evaluated individually and in combination. Conventional natural gas includes a mixture of hydrocarbons, but is mostly methane. The 




Figure 4.5.1 
energy content usually exceeds 1,000 Btu/cubic foot. Coalbed methane is also mostly methane, obviously, but can include additional gases, such as $\mathrm{N}_{2}$ and $\mathrm{CO}_{2}$, that in some areas can lower the energy content to as low as $900 \mathrm{Btu} / \mathrm{cubic}$ foot, well below pipeline quality. However, in the general region of the study area, the Btu content for Pocahontas coalbed methane has tested around $1000 \mathrm{Btu} / \mathrm{cubic}$ foot, so the methane resource is generally of very high quality iri this area.

The Beckley and Pocahontas \#3 coals were isopached using thickness data from corehole tests, mine maps and measurements from gas well logs and completion reports. Gas content figures for the individual coal seams were obtained from published data and checked for reasonableness against actual coal mine outgassing reports from mining operations. Using the isopach maps, the number of tons of coal-per-acre were calculated and this value was multiplied by 450 standard cubic feet of methane perton for the Beckley coal, and by 520 standard cubic feet per-ton for the Pocahontas coal. The individual methane-resource-per-acre estimates for the Beckley and Pocahontas \#3 coalbeds were then determined. A Total Methane Content Map was prepared by adding these values together.

The Eccles Quadrangle contains in excess of 37,000 acres and has been penetrated by 103 wells. Ninety-two wells, or about 90 percent, were successful. Over 5,000 acres have been proved productive, leaving approximately 32,000 acres, 86 percent of the quadrangle, either dry or untested. Most of the natural gas on this quadrangle has been produced from the Greenbrier "Big Lime" Limestone, with Ravencliff Sandstone reservoirs showing up as small localized pools. Several wells had been reported as having "Maxton" gas, but log analysis indicated that the so called Maxton Sandstones on this quadrangle may be basal sands deposited in deeply incised Ravencliff river channels.

Significant confusion exists in the formation tops listed in the data base for the Upper Maxton, Maxton and Lower Maxton Sandstones. If these units were once present in this area, they have apparently generally been reworked during Ravencliff time, with the destruction of any widespread Maxton Sandstones or gas pools in the study area.

The Weir Formation has had scattered shows and minor natural gas production on the Eccles map, but no large fields, while the Berea Sandstone appears to have been dry in all the holes where it has been tested.

Production data were obtained from numerous wells in the study area and production decline curves were generated and extrapolated to the economic limit for each available well. This "economic limit" was defined as the point at which the projected production would have declined to $120 \mathrm{Mcf}$ per month. At approximately that point, the well tending costs should equal the value of the production, assuming current gas prices, and it was assumed that the well would be plugged. With reserves-per-well estimated, a figure was calculated for the drainage radius. This permitted an MMct-per-acre-drained valve to be determined.

A Combined Resources Map was then prepared which included both the methane-resourcein-place in the coal beds and the conventional gas resources from the sandstones and limestones. This map displayed the total projected $\mathrm{mmct} /$ acre of combined resource that could be expected at any drilling location.

\subsubsection{Eccles Resenoir Characteristics}

With the primary resources of the Eccles Quadrangle identified, the next step was to determine the parameters which controlled the depositional character of the source beds and reservoir units and the formation of natural gas, as well as any major digenetic characteristics or events which may have affected the porosity of the reservoir units. 
Well logs were examined to determine porosity and water saturations. Information relative to reservoir lithology was obtained from logs, state sources and industry sontracts, and from masters' theses. Marshall Miller Associates of Bluefield, Virginia, were contracted to conduct a remote sensing study of the area. They prepared a weighted lineament-density map for the four study area quadrangles. The lineaments were assigned numerical values and the highest value areas were shown on a "Permeability Enhancement Probability Map" for the Eccles quadrangle.

\subsubsection{Eccles Reservoir Structure}

Maps were prepared of the regional structure and anomalous structural features were identified. Structure maps were prepared and first order trend surfaces identified. Fracture patterns were mapped and cross-checked against production. Positive residual structural anomalies were mapped; the resulting product was termed a "Structure Anomaly Map".

\subsubsection{Eccles Component Optimization}

Once the production analogs were identified and the resource, structure and permeability maps prepared, the information was projected into other areas where like conditions may have prevailed, producing similar reservoirs. The goal was to identify potentially similar geologic features and reservoir conditions in undrilled areas. This geostatistical representation of the data was te"med a "Component Optimization Map" and was used to select a number of potential test well locations.

\subsection{GEOLOGY AND ENERGY RESOURCE DATA COLLECTION}

A key aspect of the project was the development of a database for the study area which included information on both geology and gas production. The primary source for the geology database was the WVGES. Information relative to gas production was obtained from the State Oil and (ias Conservation Commission database and from individual oil and gas operators.

Well logs were obtained for select wells in crucial areas to assist in reservoir identification and the formulation of analog types.

\subsection{Database Development}

Most of the geological data required for the project were obtained from the WVGES. The data were available in relatively inexpensive computerized data sets; however, some computer programming skills were required to reiormat this information into a readily usable form for data analysis. The data was collated and manipulated in numerous ways to produce various displays and to create structure and isopach maps for the major reserve formations.

The WVGES information comes in computer files identified as follows:

CLO (Completions, Locations and Ownership Data) - This file contains most of the basic da'a necessary to identify the wells. Wells are listed by permit number, with additional data like operator number, county and district, field and quadrangle. Location information is provided in the form of longitude and latitude, as well as northing and easting. Surface and mineral owner names are provided, as is the well operator. Dates, surface datum and total depth are included, along with well type and classification, workover information, rig type and completion method. The natural and after stimulation flows and pressures/times are detailed, as is the well's current status; 
Strat (Stratigraphic Data) - The strat file includes formation identification and depth below "datum" as well as the datum value and datum type. The depth data is from the OG-10 form and minor formations or obscure, seldom recognized markers are generally not included. The "thickness" is also listed, although the nature or source of this number is not coded. "Thickness" may be a measired electric log value or a driller's estimate;

PayShow (Formation Depth and Show Data) - This file lists all oil or gas shows encountered, along with top and bottom of the show interval and volume before and after stimulation, as reported on the OG-10's;

Water - The water file contains a listing of the shallow and deep water-producing formations which have been reported to the WVGES, and a water quality classification code as fresh or salt water, when known;

Plugging - This file includes all the plugging data for an area available to the WVGES since this data file was created. Wells that were plugged prior to the formation of this file will not be listed in this base. Many of the wells which were plugged prior to the establishment of this file can be identified by the symbol shown on the Oil and Gas Information Service (OGIS) base maps or from paper records at the WVGES. This file is not complete, but can be useful as a check on recent plugging patterns and developments in an area of interest;

Production - The production file contains monthly and annual oil and gas well production figures and days-in-line numbers that have been reported to the WVGES. This data will vary in completeness by area and by operator. For some areas, this data base can have many wells with no data for a variety of reasons: the wells are older and were plugged prior to the start of the data file; or wells were shut in and the operator never reported any information to the WVGES; or because multiple wells were run through a single meter and no individual well production information was available. Many wells have figures for some years and no data on other years. The WVGES provides no explanation as to why data is missing, but does include a code to identify the source of the data.

Two significant problems were identified early in the project with the data base. One was incorrect location data, the other was incomplete data. The CLO file includes latitude and longitude. These are offered in either degrees, minutes and seconds or in decimal degrees. Several of the wells in the study had obvious problems with the locations listed. In some cases, the longitude and latitude listed in the CLO file would have placed the well on the wrong base map. In such cases, the surveyor may have recorded iricorrect numbers during the original survey, even though the graphics and sketch were correct. Typograptic or transcribing errors may have occurred in copying data onto the OG-10 forms, or in entering it from the forms into the computerized base. The CLO longitude and latitude may been miscalculated as locations were converted from minutes and seconds to decimal degrees. Location data must be reviewed with a critical eye for reasonableness at an early stage in a project.

An alternate source of well location information was available from maps prepared by the Oil and Gas Information Service (OGIS). These maps are prepared by comparing surveyor's plats to a topographic base, as well as recording numbers. An attempt is made by OGIS to reconcile any discrepancies which are noticed. Since OGIS locations are checked against a base map and are not just a series of digits, these locations should be accurate. Where potential problems existed with the locations as listed in the CLO file, the decimal locations listed were compared to the OGIS well bases. Several wells in the CLO data base proved to be almost correct in either longitude or latitude, relative to the OGIS base, but were off by $1 / 3$ of a quadrangle or by one digit in the CLO entry. For this project, the best well location information 
available was assumed to be that frorn the OGIS bases. The CLO location information was modified, when necessary, to make it coincide with the OGIS map location.

The second significant problem with the data bases was incomplete information, especially in the reporting of water, shows, flows, and production. The data were of limited use in identifying water saturated areas or for evaluating production potential since some operators reported water production faithfully while others ignored the subject. Additionally, some operators seem to report accurate flows and production, while others pay no attention to the portions of the WVGES forms concerning shows and other vital information. Use of these data bases emphasizes the importance of all operators complying quickly and completely with the WVGES in filling out filing forms carefully and accurately.

\subsection{Natural Gas Data Collection. Collation, and Analysis}

Natural gas production data was collected from the previously cited sources on a well-by-well basis. The data were used to develop decline curves. Gas simulation models were used to project cumulative production to the economic limit of each well. Average spacing between wells was measured and the drainage area for each well determined. The accepted value for the natural gas recovery factor in West Virginia is $65 \%$ of the gas originally in place. The original gas in place was calculated by dividing the estimated economically recoverable gas by the recovery factor. The gas resource was calculated by dividing the original gas in place by the area drained during production. This provided a resource in millions of cubic feet of gas per acre of area.

\subsection{Coalbed Methane Data Collection. Collation. and Analysis}

Available coal data sets and maps for the four quadrangle study area were purchased from the WVGES. The major coals, the Beckley and Pocahontas \#3 seams, were mapped for structure and thickness and maps were prepared showing the coalbed methane originally in place for each of the seams. These figures were then converted and recontoured as maps of the methane-content-per-acrefoot across the study area. Finally, the maps were modified to show the effects of the lost methane in the mined areas to produce plots of the coalbed methane-renraining-after-mining.

Once the target had been narrowed to a specific area on the Eccles Quadrangle, additional maps were obtained from a local coal operator showing more detailed isopach, structure and mined-out-area information data (see Figure 5.3.1) in the Eccles area.

The coalbed methane resource was estimated by collecting core data on coal thickness and mapping coal volume in acre-feet. Data on the gas content per ton of coal was collected from a number of sources including the U.S. Geological Survey, WVGES, U.S. Bureau of Mines, and private industry core analysis data. Using a value of $100 \mathrm{lbs}$ per cubic foot of coal as the density of the Beckley and Pocahontas coals, a total of 2,178 short tons of coal per acre foot of coal was calculated. By multiplying this number by the thickness of coal measured for each seam, the total number of tons of coal per acre was calculated. This number was then multiplied by the gas content per ton to determine the resource in place which was reported as millions of cubic feet of gas per acre.

\subsection{DATA ANALYSIS AND DEVELOPMENT OFRESERVOIR MODELS}

A review of the literature revealed that considerable research has been conducted on the depositional environments of the primary reservoir formations of southern West Virginia. This work was incorporated in the development of the reservoir models for the productive reservoir units. The initial analyses indicated that the main targets in the study area would be the Ravencliff Sandstone, the 


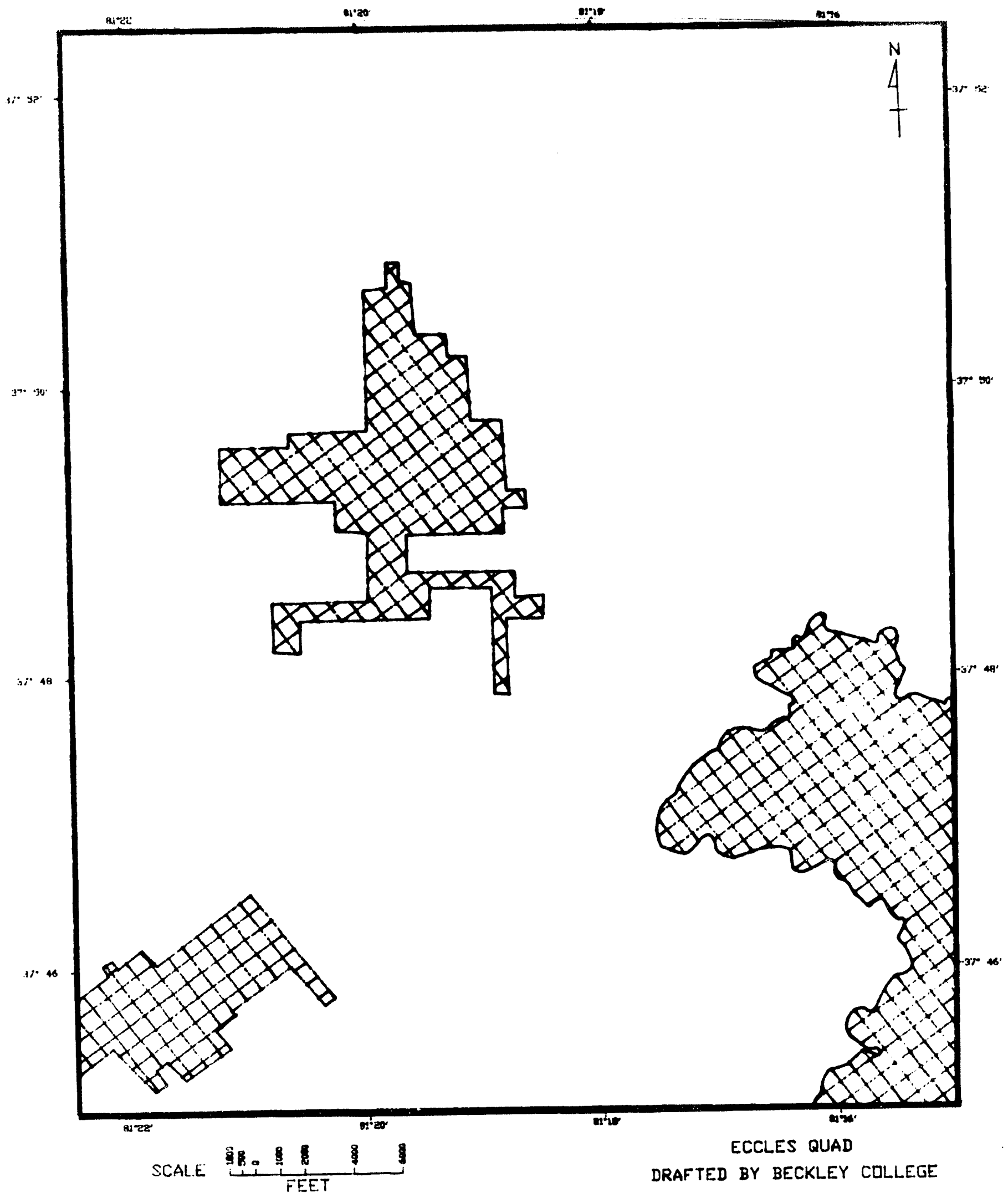

Figure 5.3.1 Mined Out Area of Eccles Quad West Virginia 
Greenbrier "Big Lime" Limestone, and the coal seams.

\subsection{Sandstone Beservoir Model Development}

Greg Wrightstone (Refs. 5 and 6) has done research on the depositional environments of the Pennsylvanian sandstones in southern West Virginia, showing that the Ravencliff Sandstones were laid down by a major river system that crossed this area. A review of the petrology and diagenesis of the Ravencliff sandstone by Kamm and Heald (Ref. 2) helped to complete the development of a reservoir model for that unit.

Analyses of well logs and geophysical logs were used to determine the location of the main Ravencliff channels and of overbank and splay deposits in this river system. Geophysical logs provided the ranges for porosity, water saturations and gas saturations in the study area. Analysis of logs and production data from specific wells led to the recognition of the importance of diagenetic alteration in determining modern reservoir quality in the Ravencliff sediments. Each of these multiple channels was probably an excellent reservoir at one time, but the best-developed channels no longer have adequate porosity or permeability to be productive in most wells. The only remaining significant Ravencliff porosity and quality reservoirs today are to be found in the thinner, slightly dirtier, sittier channels.

\subsection{Limestone Reservoir Model Development}

On the target Eccles Quadrangle, the majority of conventional natural gas reserves appears to be contained in the Greenbrier "Big Lime" Limestone. Greg Kelleher, of Consolidated Natural Gas Producing Company, New Orleans, Louisiana, has completed an unpublished Masters Thesis at West Virginia University which focuses on the Greenbrier Limestone, its clepositional environment and reservoir qualities. His study area encompasses the nine quadrangles immediately south of Lester and Crab Orchard. The lime muds that were to become the Greenbrier Limestone were deposited in a very shallow sea. In areas where wave base touched the sea floor, these muds were rolled into small pellets or oolites. Tiny spaces between the very thin layers of mud within the pellets have formed the primary "Big Lime" reservoirs. In the study area, log analyses demonstrated the presence of shoal banks with oolitic porosity on a basement high block in the east-central portion of the Eccles Quadrangle.

\subsection{Coalbed Reservoir Model Development}

The coals in southern West Virginia and on the Eccles Quadrangle are known to be very gassy, presenting a significant riazard to coal mining operations. Methane is a normal gaseous hydrocarbon by product of plant decay and coalification. The gas is normally absorbed on the surface of the solid coal material. Methane can readily desorb from the coal as the surface of the coal is exposed along fractures and through erosion or mining. The greater the amount of surface area that is exposed, either naturally or by man made activities and fracturing, the more methane that will be available for desorption. The southern West Virginia study area has been shown to have a natural cleat or fracture spacing of about $1 / 4^{\prime \prime}$. This means that these coals are especially choice targets for methane production operations because of the high surface area for desorption and the higher fracture permeability. The best methane production should come from thick, unmined coals in areas where fracturing may have been enhanced by tectonic activity or by mining activity, and where mining may have already partially dewatered the coal seam. the coal.

\subsection{LOCATION OF HIGH PROBABILITY TARGET SITES}

The optimization technique, as defined in this program, was designed toward being able to 
identify areas where the highest number of favorable factors would co-occur for each of the potential target formations. Once models were developed for each of the reservoirs in the known productive areas, it was possible to project where similar features might have formed in undrilled areas.

Maps were drafted which presented the probability of finding the various sets of resource, reservoir and structural conditions in adjacent areas for each target formation. The optimized areas for potential test wells were those with a high probability for encountering multiple pays.

\subsection{Development of Component Maps}

The primary geologic components of resource, reservoir and structure are themselves controlled by subsets of related elements (Figure 7.1.1). Figure 7.1.2 illustrates this concept by presnting various subsets of the primary element "Structure". Here, "Structure" is itself defined by a triangle, with each corner shown to be a composite of three subsets.

Structure maps were prepared for almost twenty units, with the most important and informative being the: Beckley Coal, Pocahontas \#3 Coal, Ravencliff Sandstone, Greenbrier "Big Lime" Limestone, and Berea Sandstone. Trend surface positive residual anomaly maps were prepared for the Ravencliff Sandstone and the Greenbrier Limestone (see Figure 7.1.3) and these two were combined to provide the Optimum Structure component map.

Component optimization maps for the Resource and Reservoir elements were prepared in a similar manner. The Optimized Combined Resource Map for the coalbed methane and the conventional natural gas is presented in Figure 7.1.4. The optimized map identifies all the areas with more than 8 MMcf/acre of combined resource.

The Optimized Reservoir Map was prepared by identifying the areas of original primary and secondary Ravencliff and Big Lime reservoirs and eliminating the areas with degraded, destroyed or wet potential and combining the remaining reservoir maps (see Figure 7.1.5). Methods of preparing each element component map is detailed in Volume II.

\subsection{Summary Component Optimization Map}

The final Optimization Map was prepared by combining all three component maps. The code to the patterns is given in Figure 2.0.1. Areas affected by one or any combination of two or by all three elements can be distinguished by a distinctive pattern. A large area North of Stevens Lake has the best potential for a positive effect from all three elements, and, in fact, has been penetrated by a number of the best natural gas wells on the map. This target zone has not been completely developed, and it was possible to select a test well location here with potential for good conventional natural gas and coalbed methane production.

\subsection{Site Selection Process}

Several verification test wells are to be completed as part of this project. The program objective is to drill and develop the maximum amount of natural gas and methane resource in a highly permeable reservoir in an area with a favorable structural setting. There were restrictions on the test well location, requiring the wells to be at least 700 feet from any coal mining operations to insure good production from the coal seams and 1200 feet from any producing gas wells to ensure adequate reservoir pressure. this project.

Three optimized sites were selected and leased for drilling which will be undertaken in Phase II of 


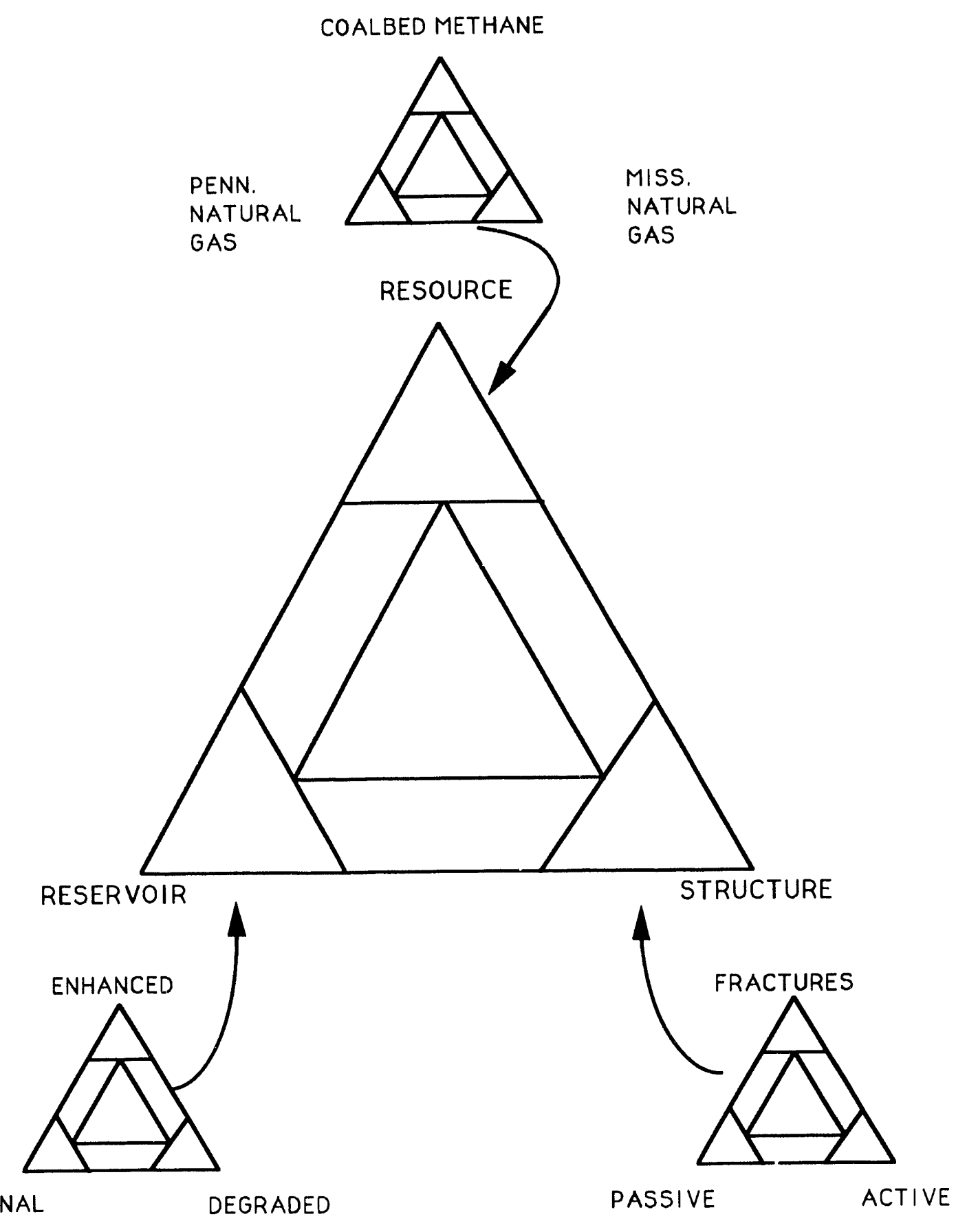

Figure 7.1 .1

Subsets of the Primary Elements 


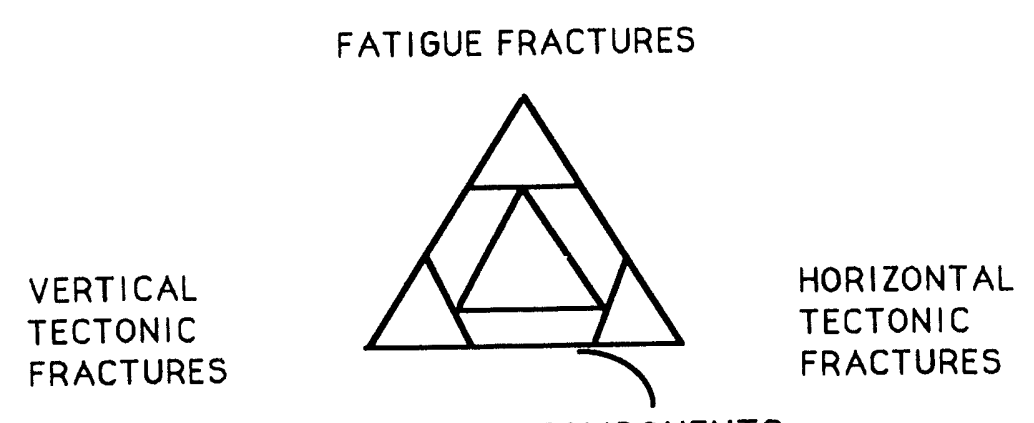

NON-CLOSURE COMPONENTS

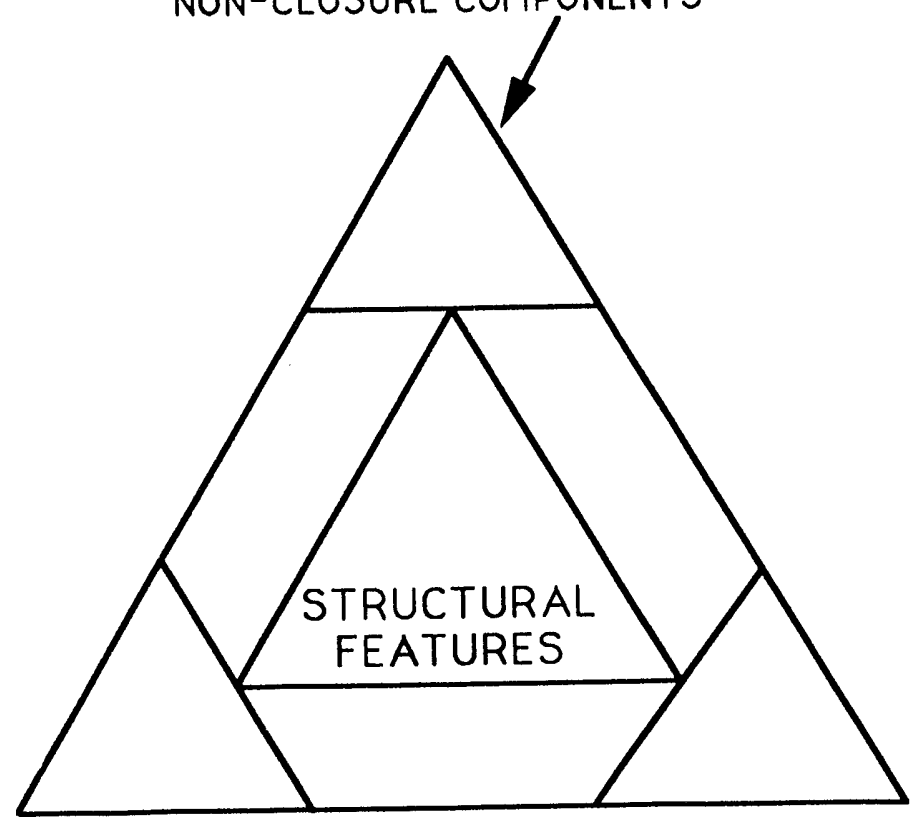

PASSIVE CLOSURE COMPONENTS

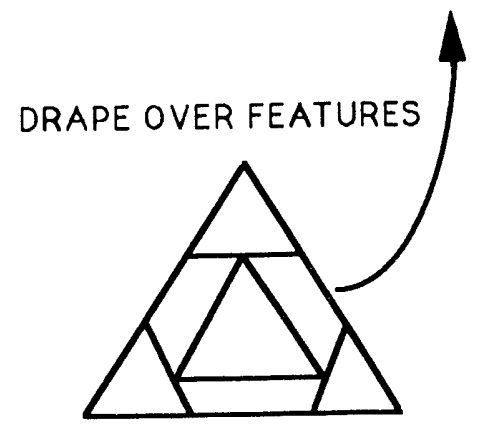

DEPOSITIONAL BASIN

TECTONIC CLOSURE COMPONENTS

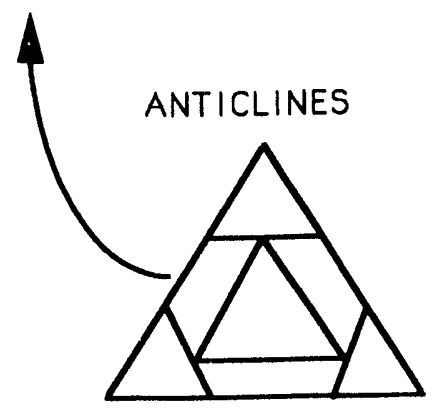

SYNCLINES

FAULT BLOCKS

Figure 7.1 .2

Subsets of the "Structure" Element 


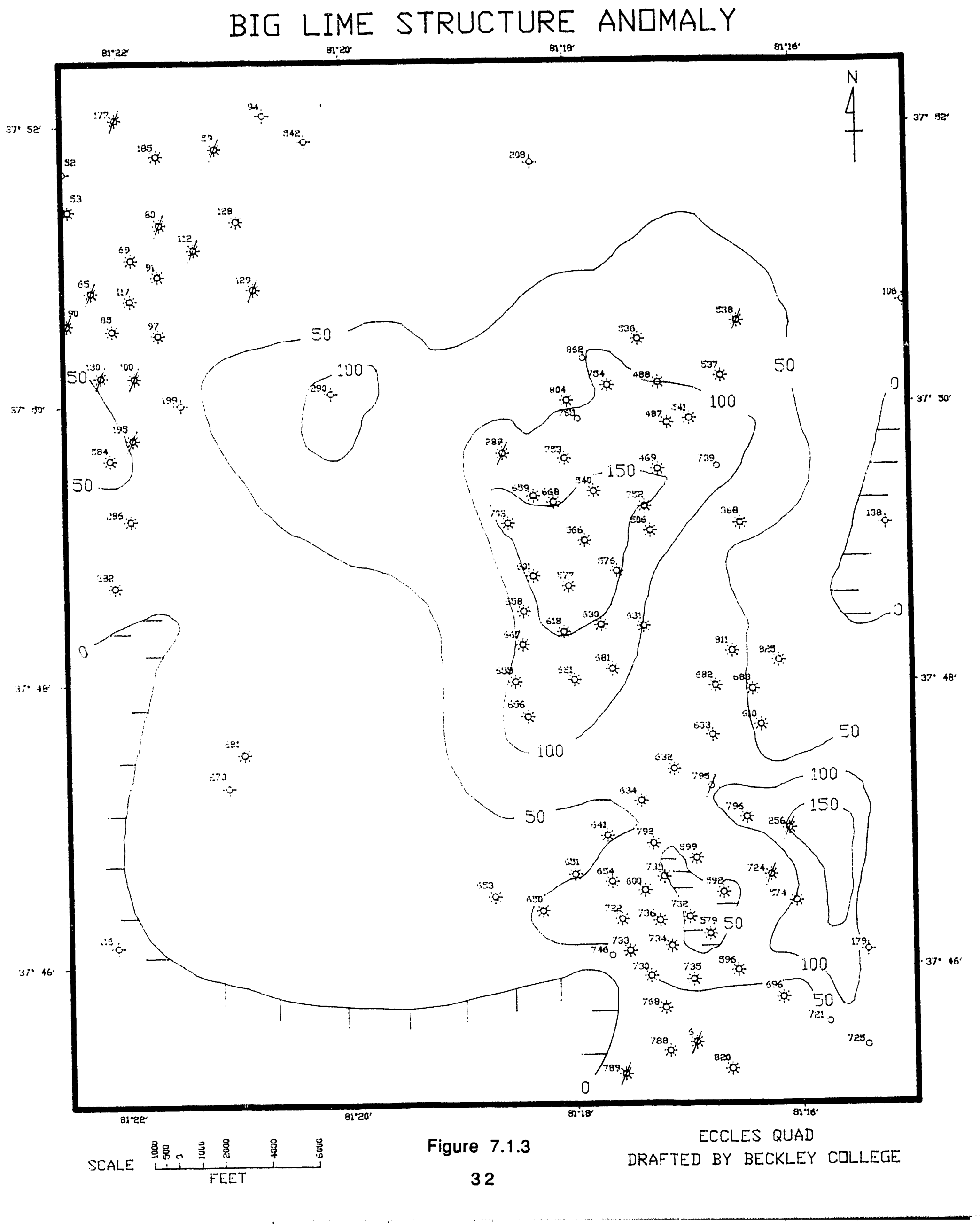




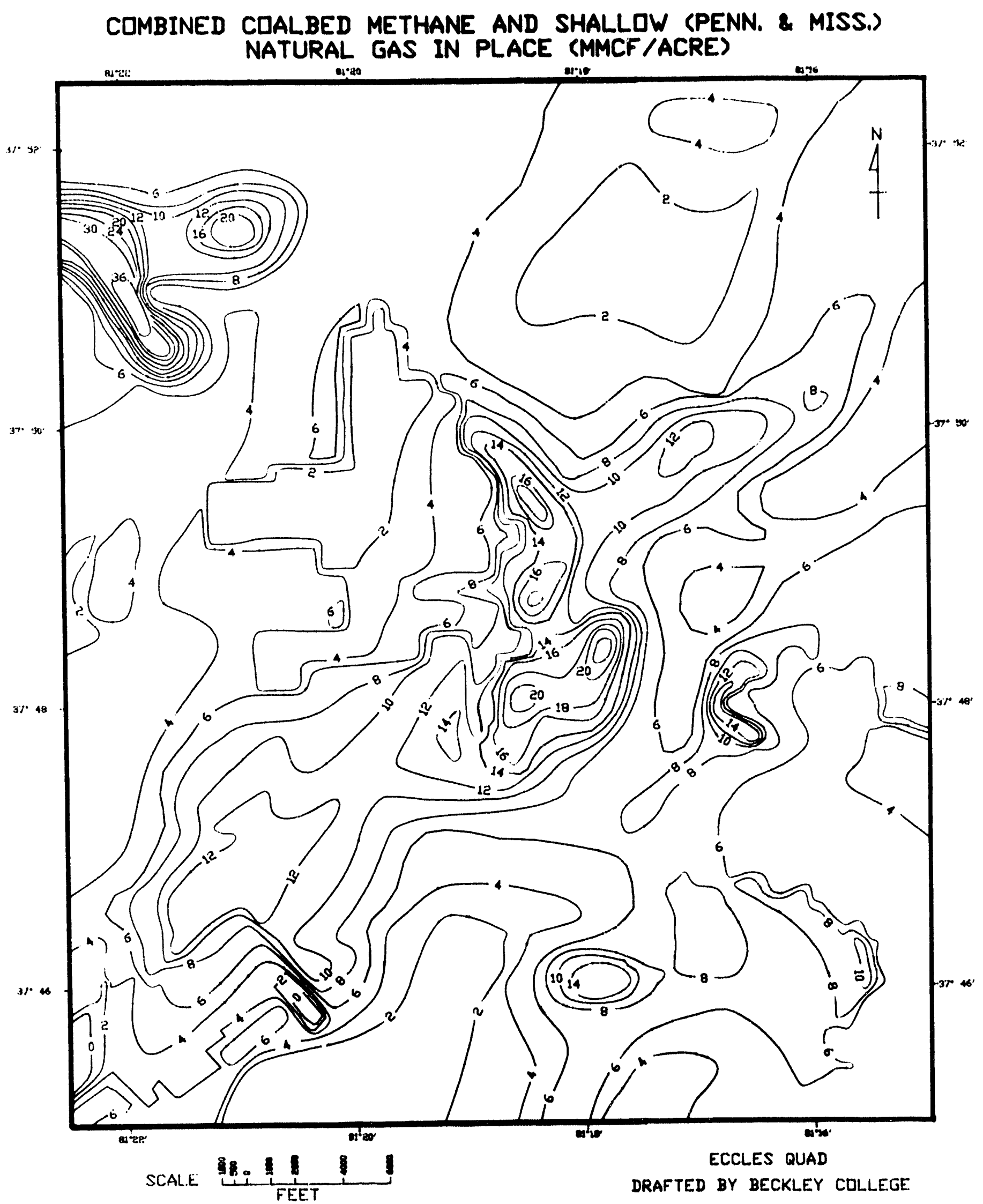

Figure 7.1.4 


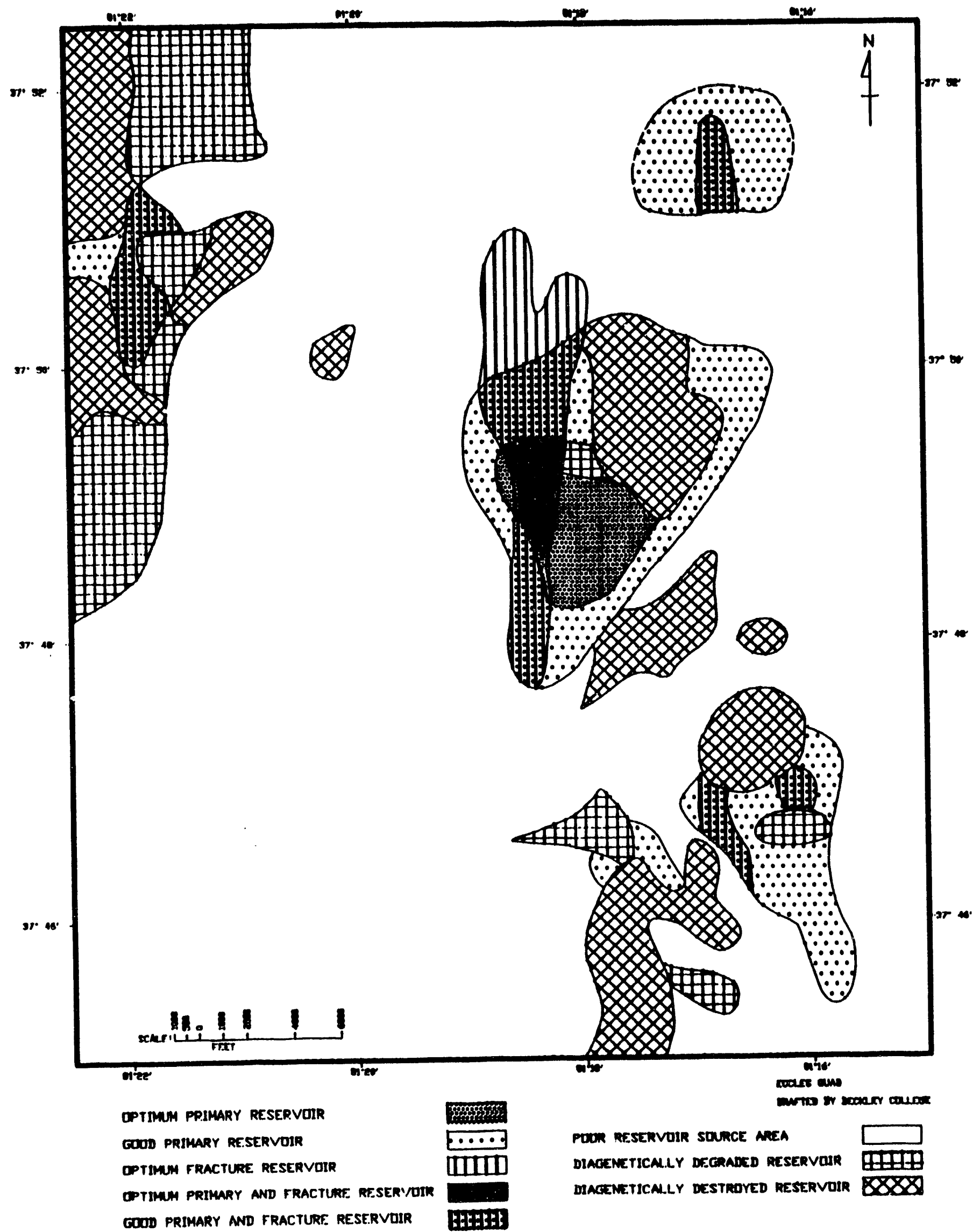

Figure 7.1.5

Big Lime Present Day Reservoir 


\section{BIBLIOGRAPHY}

1. Boswell, R.M. and Jewell, G.A., 1988. Atlas or Upper Devonian/Lower Mississippian Sandstones in the Subsurface of West Virginia; West Virginia Geologica! and Economic Survey, Circular C-43.

2. Kamm, M.W. and Heald, M.T., 1983. Petrology and Diagenesis of the Ravencliff Sandstone in West Virginia; Southeastern Geology, V. 24, No. 1.

3. Kelleher, G.T., 1990. Stratigraphy and Diagenesis of the Greenbrier Group in the Rhodell Field Area of Southern West Virginia; Unpublished Master's Thesis, West Virginia University, Morgantown, West Virginia.

4. Popp, J.T. and McCulloch, C.M., 1976. Geological Factors Affecting Methane in the Beckley Coalbed; U.S. Department of Interior, Bureau of Mines Report of Investigations, No. 8137, 35 p.

5. Wrightstone, G.R., 1984. Ravencliff Becomes Exploration Target; Northeast Oil Reporter, V. 4, No. 9, pp 33-41.

6. Wrightstone, G.R., 1985. The Stratigraphy and Depositional Environment of the Ravencliff Formation in McDowell and Wyoming Counties; Unpublished Master's Thesis, West Virginia University, Morgantown, West Virginia. 

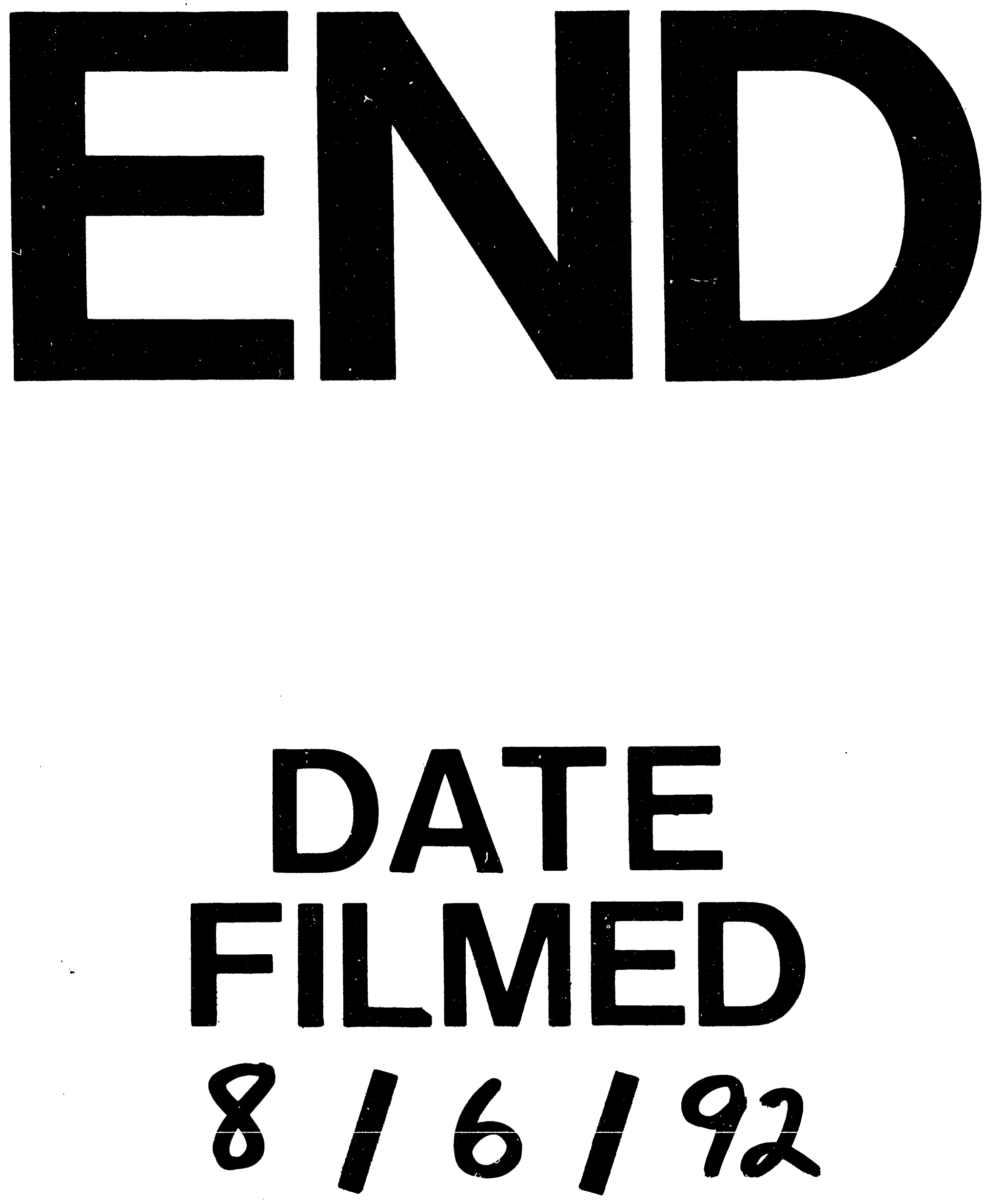
